\title{
What Do Credit Markets Tell Us About the Speed of Leverage Adjustment?
}

\author{
Redouane Elkamhi \\ Rotman School of Management, University of Toronto, Toronto, Ontario M5S 3E6, Canada, \\ redouane.elkamhi@rotman.utoronto.ca \\ Raunaq S. Pungaliya \\ Graduate School of Business, Sungkyunkwan University, Seoul 110-745, Korea, raunaq@skku.edu \\ Anand M. Vijh \\ Tippie College of Business, University of Iowa, Iowa City, Iowa 52242, anand-vijh@uiowa.edu
}

\begin{abstract}
This paper proposes a new methodology to infer investors' expectations about the speed of leverage adjust1 ment implicit in the prices of credit instruments. On average, the credit markets imply a fairly rapid annual speed of adjustment of $26 \%$ toward a firm's predicted leverage. The speed varies considerably across partitions formed by the differential implications of the pecking order, market timing, and trade-off theories of capital structure. This finding suggests that investors' expectations are formed in accordance with all three theories. We also show that the addition of firm fixed effects in the predicted leverage model gives noisier estimates of investors' expectations of future leverage, and that a firm's initial leverage is a poor estimate of its future leverage.
\end{abstract}

Data, as supplemental material, are available at http://dx.doi.org/10.1287/mnsc.2013.1871.

Keywords: capital structure; speed of adjustment; bond spread; CDS spread; predicted leverage

History: Received January 19, 2013; accepted October 15, 2013, by Jerome Detemple, finance. Published online in Articles in Advance April 9, 2014.

\section{Introduction}

Does capital structure matter? If so, then how do firms determine their optimal capital structure and how fast do they adjust toward it? These questions have been central to an extensive corporate finance literature. Many authors examine the relationship between leverage and firm characteristics and the speed of adjustment (SOA) toward the predicted leverage emerging from such a relationship. There has been a large variation in their estimated SOAs arising predominantly from differences in their methodologies (see Appendix A), which suggests the need for new evidence based on new techniques. One common feature across all previous studies has been that they rely on the time series of realized leverage changes in estimating the SOA.

In this paper, we deviate from previous approaches by providing the first market implied estimates of SOA. More explicitly, we infer investors' expectations of leverage changes implicit in the prices of credit instruments, namely, corporate bonds and credit default swap (CDS) contracts, using a generalized method of moments (GMM) approach. Credit spreads depend not only on current leverage, but also on the expected future leverage values (Collin-Dufresne and Goldstein 2001), and thus contain expectations about the speed at which investors expect a firm's leverage to change. Our proposed methodology of inferring SOA can be compared to the classical approach of using option prices to imply stock return volatility, instead of depending exclusively on realized returns. This approach circumvents many difficult econometric issues involved in capital structure tests using the traditional time-series methodology (Shyam-Sunder and Myers 1999, Chang and Dasgupta 2009, Flannery and Hankins 2012).

We show that the CDS market implies a fairly rapid adjustment process with an implied annual SOA of $26 \%$ toward the predicted leverage for our aggregate sample. ${ }^{1}$ This predicted leverage is calculated from a cross-sectional model that relates leverage to firm characteristics and year and industry fixed effects. We further document a wide variation in SOA toward the predicted leverage across several partitions where the interactions of the three major theories of capital structure-pecking order, market timing, and tradeoff-suggest short-term leverage changes in the same or opposite direction to long-term predicted leverage

\footnotetext{
${ }^{1}$ An annual speed of adjustment of $26 \%$ translates into a half-life of leverage deviation of 2.3 years (i.e., $(1-0.26)^{2.3}=0.5$, or it takes 2.3 years for the firm to move half way toward its target).
} 
changes. Our results are consistent with an emerging synthesis of the three major capital structure theories as seen in Fama and French (2005), Kayhan and Titman (2007), Byoun (2008), and Huang and Ritter (2009).

More specifically, we use a sample of 6,580 bonds during 2002 to 2007 and 6,530 CDS contracts during 2000 to 2007 and establish a cross-sectional model of bond and CDS spreads based on an extensive literature. To this model we add the (long-term) predicted leverage as an additional factor. We find two results. First, the coefficient of (current) leverage is relatively unaffected. Second, the coefficient of predicted leverage is significant and larger than the coefficient of leverage. On average, a $1 \%$ change in the predicted leverage increases bond and CDS spreads by two to three basis points in the aggregate sample. The effect is further confirmed in a matched-bond experiment that controls for all major determinants of bond risk. These results are consistent with the evidence in Flannery et al. (2012). However, this study differs from the latter paper in many respects; in particular, we focus on providing a methodology for estimating market implied SOA and its implication for the three major theories of capital structure.

Assuming a standard partial adjustment process of (current) leverage to the predicted (long-term) leverage, we next derive an expression for the expected average leverage over the life of a credit instrument. This expression combines leverage and predicted leverage in proportions that depend on SOA and time to maturity. We use the expected average leverage in place of leverage in the credit spread model, which is consistent with structural models of dynamic leverage (Collin-Dufresne and Goldstein 2001). Using a GMM approach, we then analyze the term structure of CDS contracts with one to five years to maturity to obtain robust estimates of SOA. Our SOA estimates of $26 \%$ annually in the aggregate sample are approximately the middle of SOA estimates from the previous literature summarized in Appendix A. Thus, credit market participants seem to agree neither with Fama and French (2002), who conclude that the mean reversion of leverage toward the predicted or target leverage is at a snail's pace of as little as 7\%, nor with Flannery and Rangan (2006), who conclude that the mean reversion is at a remarkably fast pace of as much as $38 \%$.

We next examine whether leverage expectations support multiple theories of capital structure. Recent finance literature views the three major theories listed above as plausible explanations of how capital structure evolves over time. These tests are similar in spirit to those of Faulkender et al. (2012), who also examine multiple theories. However, an important difference is that our paper contributes to testing this hypothesis not from the lens of the leverage time series, but from using credit market expectations about leverage evolution.

We start by identifying partitions of data based on the implications of pecking order theory (whether a firm has a current deficit or surplus), market timing theory (whether the stock is underpriced or overpriced), and trade-off theory (whether the leverage is below or above a target leverage-which we proxy by the predicted leverage). We find the lowest SOA (13\%) in partitions where both pecking order and market timing theories suggest (short-term) leverage changes away from the (long-term) predicted leverage. Similarly, we find medium SOA (30\%) in partitions where either the pecking order or the market timing theory suggests leverage changes away from the predicted leverage while the other suggests leverage changes in the same direction. In the third case where both pecking order and market timing theories suggest leverage changes in the same direction as the predicted leverage, we find the highest SOA $(36 \%)$. The combined evidence, detailed in $\S 5$, supports our hypothesis that investors' expectations are formed in accordance with all three theories.

We next use our methodology to shed new light on a current controversy related to the inclusion or exclusion of firm fixed effects in the predicted leverage model to estimate the SOA. Flannery and Rangan (2006) and Lemmon et al. (2008) argue that firm fixed effects capture firm-specific heterogeneity not captured by firm characteristics, which leads to a more precise estimate of the predicted leverage. In support of this argument they show that the inclusion of industry fixed effects explains a greater proportion of the variability in leverage values and leads to a higher SOA toward the presumed more precise estimates of predicted leverage. However, others have argued that the inclusion of firm fixed effects also creates a look-ahead bias with the traditional time-series methodology and artificially increases SOA as leverage naturally reverts to its mean value based in part on the future leverage values (Bond 2002, Parsons and Titman 2009, Hovakimian and Li 2011). In comparison, our methodology examines investor expectations at a given point in time and does not suffer from this look-ahead bias. In fact, the inclusion of future information that is not a part of investors' expectations should act like a noise with our methodology and reduce the SOA toward a noisy predicted leverage.

Our tests based on credit spreads indicate that in the aggregate sample SOA decreases from $26 \%$ to $17 \%$ with the inclusion of firm fixed effects in the predicted leverage model. This evidence implies that the SOAdecreasing effects of the look-ahead bias dominate the 
SOA-increasing effects of capturing unobserved firmspecific heterogeneity. Thus, SOA estimates of studies employing firm fixed effects and using the traditional time-series methodology are likely to be overstated. Furthermore, in the same spirit, we show that SOA decreases to $5 \%$ when initial leverage at the time of inclusion of a firm in the Compustat database is used as a measure of the predicted future leverage as suggested by Lemmon et al. (2008).

We present several robustness tests of our procedures. First, we show that all our results are robust to using observed equity volatility, calculated asset volatility, and implied equity volatility (from equity options) in the credit spread models. Second, we show that our SOA results are similar with different combinations of one-year, two-year, and five-year CDS spreads. Third, one may question the $t$-statistics of the implied SOA. To address this concern we use a bootstrapping procedure. We find that the bootstrapped values of the implied SOA using partial samples lie within a small range of the reported values using full samples. Fourth, we show that our methodology leads to SOA estimates within size and industry partitions that are consistent with our priors.

In summary, our paper provides the first documented evidence on the implied speed of leverage adjustment using credit spreads that depend on the investors' expectations of future leverage values at a given point in time. This speed of adjustment toward a long-term predicted leverage is $26 \%$. In addition, we provide critical credit-market evidence on the implied SOA within several partitions to show that the alternate pecking order, market timing, and trade-off theories all contribute to the evolution of capital structure in investors' minds. Finally, we show that the introduction of firm fixed effects in the basic predicted leverage model does not provide a better measure of the leverage expectations of credit market investors, and that the initial leverage is a poor proxy for the predicted future leverage.

\section{Model and Methodology}

\subsection{Leverage, Credit Spreads, and SOA}

Structural models of default use contingent-claims analysis to determine the value of risky securities. In Merton's (1974) model, the face value of a firm's debt acts as the strike price of a put option on the firm's assets that the bondholders have sold to the stockholders. He assumes debt to be constant over the life of the bond. Thus, traditional models specify the following relation between credit spread (which includes both bond and CDS spread) and leverage (which equals the debt value divided by the asset value):

$$
\text { Credit spread }=f(\text { Leverage, } \text { Control variables }) \text {. }
$$

The coefficient of leverage is always positive as a higher debt level increases the value of the put option (Collin-Dufresne et al. 2001, Cremers et al. 2008).

Collin-Dufresne and Goldstein (2001) and Goldstein et al. (2001) build on the insight of Merton (1974) and show that if leverage is expected to increase (decrease) over future periods, then the default risk of bond will be higher (lower) than what one may estimate by assuming constant leverage. We combine their insight with the implications of the capital structure theories. These theories suggest that there is a certain expected leverage based on current firm characteristics. ${ }^{2}$ However, because of the finite transaction costs of making leverage changes, this expected or predicted leverage is a long-term goal toward which the firms move gradually over time. Thus, the (long-term) predicted leverage becomes another factor in the credit spread, and the modified relation can be written as follows:

$$
\begin{aligned}
& \text { Credit spread } \\
& =f(\text { Leverage, } \text { Predicted leverage, Control variables }) .
\end{aligned}
$$

The coefficient of predicted leverage should be positive, because, all else constant, an increase in the predicted leverage increases the expected leverage during each period of the life of a credit instrument. This in turn increases the value of the put option whose exercise is triggered any time the asset value falls below the debt value at that time.

We next address the relative coefficients of leverage and predicted leverage in Equation (2). Intuitively, these coefficients should depend on the relative weights of the two factors in determining the average leverage over the life of the bond. Thus, for a credit instrument with a constant notional amount at risk at any time before maturity, Equation (2) can be rewritten as

$$
\begin{aligned}
& \text { Credit spread } \\
& \quad=f(\text { Expected average leverage, Control variables }) .
\end{aligned}
$$

Following an extensive literature, the control variables for bond spread in Equations (2) and (3) include the historical volatility of the firm, log total assets, coupon rate, the number of years to maturity, bond age, 10-year Treasury bond yield, term spread, default

\footnotetext{
${ }^{2}$ For example, the pecking order theory suggests an increasing expected leverage for firms with higher deficits typically associated with lower profitability. Similarly, the market timing theory suggests an increasing expected leverage for firms with higher stock valuations often measured by a higher market-to-book ratio. Finally, the trade-off theory suggests an increasing expected leverage for firms with lower debt shields captured by the depreciation to assets ratio, higher asset tangibility captured by the fixed assets to total assets ratio, or higher growth opportunities captured by the market-to-book ratio.
} 
spread, market volatility, and market return. The control variables for CDS spread drop coupon, years to maturity, and bond age from this list. Appendix B describes the motivation behind each control variable, and Appendix $C$ describes the calculation of all variables used in this paper. ${ }^{3}$

2.1.1. Determining Expected Average Leverage. The leverage changes implied by a partial adjustment model to a long-term predicted level can be modeled as

$$
L e v_{1}=\lambda \cdot P L e v_{1}+(1-\lambda) \cdot \operatorname{Lev}_{0}+\epsilon_{1} ;
$$

$L e v_{0}$ is the (current) leverage, $P L e v_{1}$ is the (long-term) predicted leverage estimate prevailing at time 1 based on firm characteristics at time $0, \lambda$ is the speed of adjustment, and $\epsilon_{1}$ is an error term. It follows by substitution that

$$
\begin{aligned}
& \text { Lev }_{2}= \lambda \text { Lev }_{2}+\lambda(1-\lambda) \text { Pev }_{1}+(1-\lambda)^{2} \text { Lev }_{0} \\
&+(1-\lambda) \epsilon_{1}+\epsilon_{2} \\
& \cdots \\
& \text { Lev }_{t-1}=\left\{\lambda \operatorname{Lev}_{t-1}+\lambda(1-\lambda) \text { PLev }_{t-2}+\lambda(1-\lambda)^{2} \text { PLev }_{t-3}\right. \\
&\left.+\cdots+\lambda(1-\lambda)^{t-2} \text { PLev }_{1}\right\}+\left\{(1-\lambda)^{t-1} \text { Lev }_{0}\right\} \\
&+\left\{(1-\lambda)^{t-2} \epsilon_{1}+(1-\lambda)^{t-3} \epsilon_{2}+(1-\lambda)^{t-4} \epsilon_{3}\right. \\
&\left.+\cdots+\epsilon_{t-1}\right\} . \quad(5)
\end{aligned}
$$

Standing at time 0 an investor can observe $L e v_{0}$ and knows predicted leverage for next period $\left(P L e v_{1}\right)$. The investor also knows speed of adjustment $(\lambda)$. We assume that the investor's best guess of predicted leverage at subsequent time points is the same as predicted leverage at time 1 . In other words, $E_{0}\left(P L e v_{\tau}\right)=$ $P L e v_{1}$, for all $\tau>1$. It follows that

$$
\begin{aligned}
E_{0}\left(\operatorname{Lev}_{t-1}\right)= & \left\{\lambda+\lambda(1-\lambda)+\lambda(1-\lambda)^{2}+\cdots+\lambda(1-\lambda)^{t-2}\right\} \\
& \cdot \operatorname{PLev}_{1}+(1-\lambda)^{t-1} \text { Lev }_{0} \\
= & \left(1-(1-\lambda)^{t-1}\right) \text { PLev }_{1}+(1-\lambda)^{t-1} \text { Lev }_{0} .
\end{aligned}
$$

We denote average leverage over the $t$ years starting at time points $0,1,2, \ldots, t-1$ by $\overline{L e v}_{0, t-1}$. It follows

\footnotetext{
${ }^{3}$ Empirical tests of credit spreads usually employ a levels model specification implied by theory and specified here as Equations (7) and (8). Sometimes an alternate changes model specification is employed, in which case the same model is tested with first-order differences of left- and right-hand variables. A changes model is necessary if the underlying time series is nonstationary. However, there is little econometric evidence for nonstationarity of credit spreads that are sampled at a low frequency, such as quarterly frequency in this paper. In unreported tests we sample BAA and AAA bond yields at quarterly intervals and reject nonstationarity. Thus, following Campbell and Taksler (2003), Yu (2005), Cremers et al. (2008), Duarte et al. (2007), and Zhang et al. (2009), we employ the levels model specification in this paper.
}

that the expected average leverage underlying a CDS contract with $t$ years to maturity can be written as

$$
\begin{aligned}
& E_{0}\left(\overline{\operatorname{Lev}}_{0, t-1}\right) \\
& =\frac{1}{t}\left\{E_{0}\left(\operatorname{Lev}_{0}\right)+E_{0}\left(\operatorname{Lev}_{1}\right)+E_{0}\left(\operatorname{Lev}_{2}\right)+\cdots+E_{0}\left(\text { Lev }_{t-1}\right)\right\} \\
& =\frac{1}{t}\left\{1+(1-\lambda)^{1}+(1-\lambda)^{2}+\cdots+(1-\lambda)^{t-1}\right\} \text { Lev }_{0} \\
& \quad+\frac{1}{t}\left\{t-\left\{1+(1-\lambda)^{1}+(1-\lambda)^{2}+\cdots+(1-\lambda)^{t-1}\right\}\right\} \text { PLv }_{1},
\end{aligned}
$$

which gives the final expression of

$$
\begin{aligned}
E_{0}\left(\overline{\operatorname{Lev}}_{0, t-1}\right)= & \frac{1-(1-\lambda)^{t}}{\lambda t} \operatorname{Lev}_{0} \\
& +\left(1-\frac{1-(1-\lambda)^{t}}{\lambda t}\right) \text { PLev }_{1} .
\end{aligned}
$$

Equation (7) shows that an increase in either $\lambda$ (the speed of adjustment) or $t$ (the time to maturity) increases the coefficient of $P L e v_{1}$ and decreases the coefficient of Lev $_{0}$.

2.1.2. Estimating Implied SOA. We illustrate the importance of predicted leverage in determining both bond and CDS spreads as given by Equation (2). However, for several reasons described in $\$ 3.2$, we estimate the implied $\lambda$, or SOA, only from CDS spreads. First, we substitute the values for expected average leverage from Equation (7) into Equation (3). Second, assuming the usual linear structure for Equation (3), taking the relevant control variables from previous literature, and knowing the values of leverage, predicted leverage, and time to maturity, we use nonlinear GMM to estimate $\lambda$ from a panel data set of CDS contracts with different maturities using the following system of equations:

$$
\begin{aligned}
& C D S_{t_{1}}=c_{1, \text { efflev }} \cdot E_{0}\left(\overline{\operatorname{Lev}}_{0, t_{1}-1}\right)+c_{1, \text { vol }} \cdot \text { VOL } \\
& +c_{1, \text { logast }} \cdot L O G A S T+c_{1, r f} \cdot R F \\
& +c_{1, \text { trmsprd }} \cdot \text { TRMSPRD }+c_{1, \text { defsprd }} \cdot \text { DEFSPRD } \\
& +c_{1, v i x} \cdot V I X+c_{1, \text { mktret }} \cdot \operatorname{MKTRET}+c_{1, \text { const }}+\epsilon_{t_{1}}, \\
& \mathrm{CDS}_{t_{2}}=c_{2, \text { efflev }} \cdot E_{0}\left(\overline{\operatorname{Lev}}_{0, t_{2}-1}\right)+c_{2, v o l} \cdot V O L \\
& +c_{2, \text { logast }} \cdot L O G A S T+c_{2, r f} \cdot R F \\
& +c_{2, \text { trmsprd }} \cdot T R M S P R D+c_{2, \text { defsprd }} \cdot \text { DEFSPRD } \\
& +c_{2, \text { vix }} \cdot \operatorname{VIX}+c_{2, \text { mktret }} \cdot \operatorname{MKTRET}+c_{2, \text { const }}+\epsilon_{t_{2}} \text {, } \\
& C D S_{t_{n}}=c_{n, \text { efflev }} \cdot E_{0}\left(\overline{\operatorname{Lev}}_{0, t_{n}-1}\right)+c_{n, \text { vol }} \cdot V O L \\
& +c_{n, \text { logast }} \cdot \text { LOGAST }+c_{n, r f} \cdot R F \\
& +c_{n, \text { trmsprd }} \cdot \text { TRMSPRD }+c_{n, \text { defsprd }} \cdot \text { DEFSPRD } \\
& +c_{n, v i x} \cdot \operatorname{VIX}+c_{n, m k t r e t} \cdot \operatorname{MKTRET} \\
& +c_{n, \text { const }}+\epsilon_{t_{n}} \text {. }
\end{aligned}
$$


The firm-specific subscripts have been suppressed in this system of equations for expositional reasons. We denote the $C D S$ spreads for contracts with $t_{1}, t_{2}, \ldots, t_{n}$ years to maturity by $C D S_{t_{1}}, C D S_{t_{2}}, \ldots, C D S_{t_{n}}$; the historical volatility and log assets of the firm by $V O L$ and LOGAST, respectively; and the 10-year Treasury bond yield, term spread, default spread, market volatility, and market return by RF, TRMSPRD, DEFSPRD, VIX, and MKTRET, respectively. Each control variable is multiplied by a coefficient with the obvious notation.

\subsection{Estimation of Predicted Leverage}

An extensive literature on tests of trade-off theory estimates target leverage by a panel regression of leverage in period $t+1$ on firm characteristics that proxy for the trade-off between costs and benefits of leverage in period $t$ (Parsons and Titman 2009). The typical model specification is as follows:

$$
\text { Leverage }_{i, t+1}=X_{i, t} \beta+\varepsilon_{i, t} .
$$

Here $X_{i t}$ is a vector of firm characteristics. Following Titman and Wessels (1988), Kayhan and Titman (2007), and Harford et al. (2009), we include the following firm characteristics as shown in Appendix D: earnings before interest and taxes (EBIT), market-to-book ratio, $\log$ total assets, depreciation, fixed assets, research and development (R\&D) dummy, R\&D expense, selling expense, and a rated dummy. In addition, we include various fixed effects as described below. All of these variables are defined in Appendix C, and their summary statistics are reported in Appendix D. Parsons and Titman (2009) describe the motivation behind the inclusion of each variable in Equation (9) in considerable detail. We measure leverage as the sum of total long-term debt and total debt in current liabilities scaled by total assets.

Panel B of Appendix D reports three different empirical estimates of Equation (9) using different specifications of vector $X_{i t}$ and conventional methodologies. Model (D.1) constitutes our base model employed throughout this paper, and it includes year and industry fixed effects in addition to the nine firm characteristics listed above. It employs a Tobit regression that constrains the leverage to lie between 0 and 1 (following Kayhan and Titman 2007). We use a sample of 100,945 firm-years for which relevant data exist on Compustat during 1967 to 2007 . We find that the coefficients of all nine firm characteristics are consistent with previous literature (Titman and Wessels 1988, Rajan and Zingales 1995, and Flannery and Rangan 2006; not all papers include all characteristics). Note that firm profitability has a negative coefficient, which many consider to be inconsistent with trade-off theory, and market-to-book ratio also has a negative coefficient, which is consistent with both trade-off theory and market timing theory. ${ }^{4}$ Using an extensive simulation analysis, Chang and Dasgupta (2006) show that the coefficient of profitability is most likely to be explained by pecking order theory, and the coefficient of marketto-book ratio is more likely to be explained by market timing theory than by trade-off theory. Following their evidence, one may argue that the fitted values obtained from model (D.1) are predicted leverage values rather than target leverage values. Predicted leverage is a possible implication of multiple theories.

Model (D.2) next includes all firm characteristics and year fixed effects but drops industry fixed effects. It is an intermediate step to the last model, (D.3), which adds firm fixed effects. Chang and Dasgupta (2006) and Lemmon et al. (2008) show that industry fixed effects are among the most influential determinants of firm leverage, and it would be hard to argue that their inclusion creates a significant lookahead bias. In comparison, Bond (2002), Parsons and Titman (2009), and Hovakimian and Li (2011) argue that the inclusion of firm fixed effects creates a lookahead bias in panel data and mechanically increases SOA. Thus, by testing both models we can separate the SOA changes resulting from not including industry fixed effects and including firm fixed effects.

Model (D.2) is estimated using a Tobit regression similar to model (D.1), and model (D.3) is estimated using the panel regression approach of Flannery and Rangan (2006). There is considerable similarity of coefficients between models (D.1) and (D.2). However, the coefficients in model (D.3) are generally smaller in magnitude compared to model (D.1), although they have the same signs except for the R\&D dummy (similar to results documented by Flannery and Rangan 2006). This finding is consistent with that of Lemmon et al. (2008), who show that in the presence of firm fixed effects, the explicitly included firm characteristics explain a lower proportion of the variability in firm leverage.

\section{Data Sources}

\subsection{Bond Sample}

We obtain bond prices and yields from the Transaction Reporting and Compliance Engine (TRACE) database from 2002 to 2007. We follow the cleaning procedure outlined in Dick-Nielsen (2009). We then

\footnotetext{
${ }^{4}$ The static trade-off theory implies a positive coefficient of profitability because profitable firms can support higher leverage without distress. Pecking order theory, on the other hand, implies a negative coefficient of profitability as more profitable firms either retain their profits or use them to repurchase debt before equity. In addition, trade-off theory implies a negative coefficient of market-to-book ratio because growth firms cannot support high leverage, but market timing theory also implies the same result because higher market-to-book ratio is associated with greater stock valuation and stock issues.
} 
merge the cleaned TRACE database with the Mergent Fixed Income Securities Database to create a working sample of regular bonds. Bonds that are convertible, putable, callable, asset backed, have floating coupons or credit enhancements, are not issued in U.S. dollars, or are not domiciled in the United States are excluded. In addition, bonds that are not senior unsecured obligations of the issuing firm or have less than one year to maturity are also excluded. Although these restrictions reduce the sample size, they ensure that bond yields under consideration are comparable with each other and their spreads are not explained by unique bond characteristics.

The TRACE database is constructed by aggregating bond transactions. Because some bonds trade multiple times a day whereas others do not trade for several days, it does not contain bond prices at regular intervals. We transform the cleaned transaction database into an end-of-day bond yield database by trade-weighting the yields of individual transactions during each trading day (Bessembinder et al. 2009). Finally, we calculate bond spreads by subtracting constant maturity Treasury yields, which are interpolated to match with the exact bond maturity.

We merge this cleaned bond spread database with the quarterly Compustat database. We require that the necessary variables to estimate the predicted leverage and the required control variables are available for included bonds. Finally, we sample bond spreads at quarterly intervals. We pick the first available bond spread after the quarterly earnings announcement date. However, if no bond spread is available within 15 days of the announcement date, we do not include an observation for that quarter. If a firm has multiple bonds, then we include all bonds with available bond spread data. Thus, we control for two-way clustering across firms and quarters. The final sample contains 6,580 bond-quarters for 1,581 bonds or 331 firms during the second quarter of 2002 (2002-Q2) to the fourth quarter of 2007 (2007-Q4).

\subsection{CDS Sample}

CDS spread can be defined as the premium paid to insure the loss of value on the underlying debt obligation against prespecified credit events. This spread reflects default risk, and it is a function of the probability of default and the loss-given-default of the underlying obligation (Longstaff et al. 2005, Ericsson et al. 2005). This contrasts with the yield spreads of corporate bonds, which reflect not only default risk, but also the risk-free benchmark yield and the differential tax treatment and liquidity of corporate bonds versus Treasury bonds (Cao et al. 2010). There are several additional reasons why CDS contracts are better suited than bonds for testing some of our hypotheses. First, whereas bonds age over time, CDS spreads are quoted daily for a fixed term to maturity. Second, unlike corporate bond spreads that are recorded by TRACE only when the underlying bond trades, CDS quotes are available on a daily basis for a large number of firms. Third, it may be argued that due to greater liquidity, CDS contracts react faster to new information than bonds. In summary, the CDS spread is a cleaner and timelier measure of default risk of the firm over a given time to maturity than bond spread. The inclusion of CDS data thus increases the reliability of our results.

We collect single-name CDS spreads from a comprehensive database compiled by Markit. Daily CDS spreads reflect the average quotes contributed by major market participants. This database has already been cleaned to remove outliers and stale quotes. We require that two or more banks quote a CDS spread to include it as an observation (Cao et al. 2010).

Our sample includes U.S. dollar-denominated CDS contracts on senior unsecured obligations with modified restructuring (MR), which happen to be the most liquid CDS contracts in the U.S. market (Duarte et al. 2007). We attempt a fair representation of the term structure of CDS spreads by including one-year, twoyear, and five-year contracts in our measurement of implied SOA. Finally, we use the average CDS spread calculated over five trading days after the quarterly earnings announcement date. Our final sample contains 6,530 CDS-quarters for 447 firms during 2000-Q4 to $2007-\mathrm{Q} 4$.

\subsection{Summary Statistics of the Bond and CDS Samples}

Panel A of Table 1 reports the summary statistics for the sample of 6,580 bonds during 2002-Q2 to 2007-Q4. The median bond and firm characteristics are as follows: bond spread, 84 basis points; time to maturity, 6.0 years; bond age, 4.0 years; coupon, $6.3 \%$ per annum; firm assets, $\$ 18.4$ billion; and historic equity volatility, $23.2 \%$ annually. The median macroeconomic variables are as follows: 10-year Treasury bond yield, 446 basis points; term spread, 31 basis points; default spread, 91 basis points; market volatility, $14.6 \%$ annually; and market return, $14.7 \%$. The median predicted leverage is $27.5 \%$ with an interquartile range of $7.6 \%$.

Panel B of Table 1 shows the sample of 6,530 CDS contracts with five years to maturity during 2000-Q4 to 2007-Q4. This sample has many firm characteristics and macroeconomic variables similar to the bond sample. However, the median CDS spread is 56 basis points (compared to 84 basis points for bonds), and the underlying firms have median assets of $\$ 6.1$ billion (compared to $\$ 18.4$ billion for bonds). The CDS spreads are lower because these are mainly compensation for default risk, unlike bond spreads that also include tax and liquidity effects. The lower firm assets for the CDS sample suggest that CDS contracts are 
Table 1

Summary Statistics

\begin{tabular}{|c|c|c|c|c|}
\hline Variable & Mean & Q1 & Median & Q3 \\
\hline \multicolumn{5}{|c|}{ Panel A: Bond sample—levels model $-6,580$ observations } \\
\hline Bond spread-all (basis points) & 116 & 56 & 84 & 135 \\
\hline Leverage (\%) & 29.9 & 20.4 & 27.1 & 37.2 \\
\hline Predicted leverage-no firm fixed effects (\%) & 28.5 & 24.4 & 27.5 & 32.0 \\
\hline Initial leverage (\%) & 18.6 & 1.8 & 13.5 & 28.5 \\
\hline Historical equity volatility—annualized (\%) & 25.3 & 18.5 & 23.2 & 29.7 \\
\hline Assets ( $\$$ billions) & 45.9 & 7.4 & 18.4 & 38.7 \\
\hline Coupon $(\%)$ & 6.2 & 5.3 & 6.3 & 7.1 \\
\hline Years to maturit & 8.9 & 3.3 & 6.0 & 9.5 \\
\hline Bond age (year & 4.2 & 2.0 & 4.0 & 6.0 \\
\hline 10-year Treasur & 449 & 418 & 446 & 473 \\
\hline Term spread (ba & 75 & 2 & 31 & 152 \\
\hline Default spr & 89 & 81 & 91 & 94 \\
\hline Market volatility-VIX $(\%)$ & 15.3 & 12.0 & 14.6 & 16.9 \\
\hline Market return (\%) & 14.0 & 9.4 & 14.7 & 19.0 \\
\hline \multicolumn{5}{|c|}{ Panel B: CDS sample-6,530 observations } \\
\hline 5-year CDS spread (basis points) & 113 & 30 & 56 & 141 \\
\hline Leverage (\%) & 28.9 & 18.7 & 26.4 & 36.6 \\
\hline Predicted leverage-no firm fixed effects (\%) & 28.2 & 23.9 & 27.6 & 32.4 \\
\hline Initial leverage (\%) & 21.9 & 1.7 & 15.5 & 33.7 \\
\hline ity volatility—annualized (\%) & 30.2 & 22.0 & 28.1 & 36.0 \\
\hline Historical asset volatility — annualized (\%) & 26.8 & 19.8 & 24.8 & 31.4 \\
\hline Implied equity volatility - annualized (\%) & 31.4 & 23.2 & 29.2 & 37.4 \\
\hline Assets ( $\$$ billions) & 12.9 & 3.1 & 6.1 & 14.4 \\
\hline 10-year Treasury bond yield (basis points) & 444 & 415 & 445 & 472 \\
\hline Term spread (basis points) & 101 & 10 & 69 & 203 \\
\hline Default spread (basis points) & 94 & 82 & 91 & 103 \\
\hline Market volatility $(\%)$ & 17.3 & 12.8 & 15.4 & 20.2 \\
\hline Market return (\%) & 10.9 & 5.6 & 14.0 & 18.5 \\
\hline $\begin{array}{l}\text { 1-year CDS spread-5,684 cases } \\
\text { (basis points) }\end{array}$ & 62 & 9 & 20 & 60 \\
\hline $\begin{array}{l}\text { 10-year CDS spread-5,632 cases } \\
\text { (basis points) }\end{array}$ & 129 & 44 & 76 & 160 \\
\hline
\end{tabular}

Notes. Panel A reports the summary statistics for the bond sample, and panel $B$ reports the same for the CDS sample. The sample period for bonds starts in 2002-Q2 and ends in 2007-Q4. We include bonds with all maturities and credit ratings for which the required quarterly data are available. The CDS sample period starts in 2000-Q4 and ends in 2007-Q4. We include MR-class CDS contracts with constant five years to maturity for which the required quarterly data are available. Appendix $C$ defines the variables analyzed, and Appendix $D$ describes the models used to estimate predicted leverage. For brevity, we report only predicted leverage statistics from model (D.1).

also traded on smaller firms with less liquid bonds. This may explain why the historical equity volatility, historical asset volatility, and implied equity volatility of firms underlying the CDS sample equal $28.1 \%$, $24.8 \%$, and $29.2 \%$ per annum, respectively, higher than the historic equity volatility of $23.2 \%$ for firms underlying the bond sample. In the following sections we present analyses of both bond and CDS spreads.

\section{Credit Spreads, Predicted Leverage, and Speed of Adjustment}

\subsection{Do Bond and CDS Markets Price Predicted Leverage?}

Table 2 shows three different model specifications for both bond and CDS spreads. The first sample includes
6,580 bond-quarters for which the relevant data are available. Given the pooled time-series and crosssectional nature of this sample, we base our inferences on two-way clustered $t$-statistics. Model (2.1) shows that previously known and tested firm-specific, bondspecific, and macroeconomic variables give an $R^{2}$ of 0.511. In addition, the coefficients of most variables are in line with previous literature as explained in §2.2. The coefficient of leverage equals 1.48 with a $t$-statistic of 4.05 .

Model (2.2) shows that in a univariate regression predicted leverage is a highly significant determinant of bond spread with a $t$-statistic of 3.87 and an $R^{2}$ of 0.081 . Model (2.3) next includes all the variables from (2.1) based on previous literature plus predicted leverage. The coefficient of leverage goes down only slightly from 1.48 to 1.31 , significant at $1 \%$ level. The coefficient of predicted leverage equals 2.47, larger than the coefficient of leverage, and significant at $1 \%$ level. The addition of predicted leverage increases the $R^{2}$ from 0.511 to 0.528 . Although that is a significant increase in $R^{2}$, it understates the contribution of predicted leverage as the incremental $R^{2}$ of any variable in a multivariate regression depends on the order in which the variables are added to the regression. These bond market results are consistent with those of Flannery et al. (2012), who use a changes model and find that bond spreads anticipate future leverage changes.

Models (2.4), (2.5), and (2.6) show a similar but stronger role for both leverage and predicted leverage in CDS spreads. This sample includes 6,530 CDSquarters with five years to maturity for which the relevant data are available. Leverage has a coefficient of 3.21 in the traditional specification without predicted leverage in (2.4). In comparison, leverage has a coefficient of 2.79 and predicted leverage has a coefficient of 3.09 in the enhanced specification of (2.6). All coefficients are significant at $1 \%$ level. The $R^{2}$ increases from 0.481 with the traditional specification to 0.501 with the enhanced specification that includes predicted leverage.

Model (2.3) suggests that, holding other things constant, and on average, bond spread increases by 2.47 basis points for a $1 \%$ increase in predicted leverage. Model (2.6) suggests that CDS spread increases by 3.09 basis points for a $1 \%$ increase in predicted leverage. (Note, however, that predicted leverage has about half the cross-sectional variance of leverage as shown in Table 1.) The combined results suggest that predicted leverage is a significant factor in the pricing of credit spreads. In other words, credit market participants believe that leverage converges to a predicted value based on a cross-sectional model over some time horizon. In addition, following Equation (7), the ratio of coefficients of predicted leverage and leverage should equal $\left(\lambda t-\left(1-(1-\lambda)^{t}\right)\right) /\left(1-(1-\lambda)^{t}\right)$. Whereas 
Does the Credit Market Price Predicted Leverage?

\begin{tabular}{|c|c|c|c|c|c|c|}
\hline \multirow[b]{2}{*}{ Independent variable } & \multicolumn{3}{|c|}{$\begin{array}{l}\text { Dependent variable: } \\
\text { Bond spread }\end{array}$} & \multicolumn{3}{|c|}{$\begin{array}{l}\text { Dependent variable: } \\
\text { CDS spread }\end{array}$} \\
\hline & $(2.1)$ & $(2.2)$ & (2.3) & $(2.4)$ & $(2.5)$ & (2.6) \\
\hline Leverage & $\begin{array}{l}1.48 \\
(4.05)\end{array}$ & & $\begin{array}{l}1.31 \\
(3.96)\end{array}$ & $\begin{array}{c}3.21 \\
(10.50)\end{array}$ & & $\begin{array}{c}2.79 \\
(9.85)\end{array}$ \\
\hline Predicted leverage & & $\begin{array}{c}4.88 \\
(3.87)\end{array}$ & $\begin{array}{l}2.47 \\
(3.79)\end{array}$ & & $\begin{array}{c}6.58 \\
(7.50)\end{array}$ & $\begin{array}{l}3.09 \\
(5.71)\end{array}$ \\
\hline Historical volatility of firm & $\begin{array}{l}5.20 \\
(8.61)\end{array}$ & & $\begin{array}{c}4.99 \\
(8.41)\end{array}$ & $\begin{array}{c}6.89 \\
(14.46)\end{array}$ & & $\begin{array}{c}6.61 \\
(14.58)\end{array}$ \\
\hline Log total assets & $\begin{array}{l}-10.33 \\
(-3.57)\end{array}$ & & $\begin{array}{l}-13.00 \\
(-4.55)\end{array}$ & $\begin{array}{l}-9.70 \\
(-2.65)\end{array}$ & & $\begin{array}{l}-11.88 \\
(-3.31)\end{array}$ \\
\hline Coupon & $\begin{array}{l}17.27 \\
(5.37)\end{array}$ & & $\begin{array}{l}13.87 \\
(4.88)\end{array}$ & & & \\
\hline Years to maturity & $\begin{array}{c}1.63 \\
(6.73)\end{array}$ & & $\begin{array}{l}1.67 \\
(6.90)\end{array}$ & & & \\
\hline Bond age & $\begin{array}{c}0.77 \\
(0.59)\end{array}$ & & $\begin{array}{l}1.14 \\
(0.89)\end{array}$ & & & \\
\hline 10-year Treasury bond yield & $\begin{array}{l}-0.14 \\
(-1.09)\end{array}$ & & $\begin{array}{l}-0.14 \\
(-1.08)\end{array}$ & $\begin{array}{l}-0.08 \\
(-0.56)\end{array}$ & & $\begin{array}{l}-0.09 \\
(-0.63)\end{array}$ \\
\hline Term spread & $\begin{array}{l}-0.49 \\
(-6.33)\end{array}$ & & $\begin{array}{l}-0.45 \\
(-5.97)\end{array}$ & $\begin{array}{l}-0.27 \\
(-4.94)\end{array}$ & & $\begin{array}{l}-0.25 \\
(-4.85)\end{array}$ \\
\hline Default spread & $\begin{array}{l}-1.03 \\
(-3.99)\end{array}$ & & $\begin{array}{l}-0.98 \\
(-3.92)\end{array}$ & $\begin{array}{l}-0.50 \\
(-1.46)\end{array}$ & & $\begin{array}{l}-0.54 \\
(-1.65)\end{array}$ \\
\hline Market volatility (VIX) & $\begin{array}{c}6.65 \\
(5.60)\end{array}$ & & $\begin{array}{c}6.44 \\
(5.35)\end{array}$ & $\begin{array}{c}2.51 \\
(3.40)\end{array}$ & & $\begin{array}{c}2.43 \\
(3.47)\end{array}$ \\
\hline Market return & $\begin{array}{c}1.17 \\
(3.29)\end{array}$ & & $\begin{array}{c}1.10 \\
(3.09)\end{array}$ & $\begin{array}{c}0.87 \\
(2.61)\end{array}$ & & $\begin{array}{c}0.82 \\
(2.61)\end{array}$ \\
\hline Constant & $\begin{array}{l}-11.93 \\
(-0.23)\end{array}$ & $\begin{array}{l}-23.49 \\
(-0.72)\end{array}$ & $\begin{array}{l}-29.46 \\
(-0.59)\end{array}$ & $\begin{array}{l}-44.36 \\
(-0.82)\end{array}$ & $\begin{array}{l}-72.37 \\
(-3.30)\end{array}$ & $\begin{array}{c}-85.71 \\
(-1.62)\end{array}$ \\
\hline $\begin{array}{l}\text { Adjusted } R^{2} \\
\text { Observations }\end{array}$ & $\begin{array}{l}0.511 \\
6,580\end{array}$ & $\begin{array}{c}0.081 \\
6,580\end{array}$ & $\begin{array}{c}0.528 \\
6,580\end{array}$ & $\begin{array}{c}0.481 \\
6,530\end{array}$ & $\begin{array}{c}0.102 \\
6,530\end{array}$ & $\begin{array}{c}0.501 \\
6,530\end{array}$ \\
\hline
\end{tabular}

Notes. This table examines the effect of predicted leverage on bond and CDS spreads using quarterly data. The sample period for bonds starts in 2002-Q2 and ends in 2007-Q4. We include bonds with all maturities and credit ratings for which the required quarterly data are available. The CDS sample period starts in 2000-Q4 and ends in 2007-Q4. We include MR-class CDS contracts with constant five years to maturity for which the required quarterly data are available. Models (2.1), (2.2), and (2.3) thus use the bond spread as the dependent variable, and models (2.4), (2.5), and (2.6) use the CDS spread. Appendix C defines the variables analyzed, and Appendix D describes the models used to estimate the predicted leverage. In this table we use predicted leverage from model (D.1), which includes industry and year fixed effects, but no firm fixed effects. In parentheses we report two-way clustered $t$-statistics that adjust for clustering at the firm and the calendar quarter levels. The $t$-statistics greater than $2.58,1.96$, and 1.64 are statistically significant at the $1 \%, 5 \%$, and $10 \%$ levels, respectively.

the bond sample contains a mix of bonds with various maturities $t$, the CDS sample has contracts with a fixed maturity of $t=5$ years. Thus, for the CDS sample it is possible to calculate the speed of adjustment $\lambda$ from the ratio of coefficients, which equals $3.09 / 2.79=1.108$. This implies a speed of adjustment of 0.384 , or $38.4 \%$ per annum. However, this inference is subject to a few caveats.

First, this SOA value is obtained by applying an ordinary least squares (OLS) procedure to CDS contracts of a single five-year maturity. We instead prefer to estimate SOA by applying the GMM procedure to CDS contracts of different maturities as shown by Equation (8). This is because relying on the term structure of CDS spreads effectively spans the short and long ends of the maturity spectrum and thus contains more information on investors' expectations than one single maturity. In a parallel context, Pan and Singleton (2008) show that more reliable implied parameter values are obtained by effectively spanning the term structure of CDS maturities (in their case, default intensities and recovery rates implied by credit spreads of sovereign CDS contracts). Second, although not applicable to our methodology, previous literature shows that the OLS and GMM approaches can give different answers even when applied to a single-equation system, in which case the GMM approach is preferred. For example, Lemmon et al. (2008) find that estimating the exact same time-series model with OLS and GMM gives SOA values of 39\% and 25\% (see their Table 6). Third, estimating SOA from the ratio of coefficients of predicted leverage and leverage using a single-maturity CDS contract can also be subject to a large estimation error, especially in 
small subsamples of data, and especially if the coefficient of leverage that appears in the denominator is relatively small. ${ }^{5}$

\subsection{The Magnitude of Predicted Leverage Effect Revisited}

The regression approach of Table 2 is the most common approach followed in the literature to test the cross-sectional determinants of credit spread. Part of the reason is its tractability and its ability to accommodate multiple factors. However, this approach has the limitation that it assumes a linear specification of the underlying structural model. It is possible that the effect of leverage and volatility enters the bond spread in a nonlinear fashion as in any option pricing model. For robustness, we report an alternate experiment to measure the magnitude and statistical significance of the predicted leverage effect using a matched-bond experiment.

To understand the matching procedure, consider panel A of Table 3. We partition the aggregate sample into four quartiles based on predicted leverage. The dispersion in predicted leverage across these partitions is quite significant, with a mean value of $36.9 \%$ in the top quartile and $21.8 \%$ in the bottom quartile (medians, $35.4 \%$ and $22.3 \%$ ). Next, for each bond in the bottom quartile, we select a bond of a different firm in the top quartile that is its closest match on leverage. This procedure gives 1,810 matched pairs of bonds with similar leverage but a large difference between their predicted leverage. For a proper examination, we also report the distance to default and credit ratings, the other two determinants of default risk.

Panel A of Table 3 shows that the bond spread averages 81.2 basis points for the low predicted leverage quartile and 155.2 basis points for the high leverage quartile (medians, 66.0 and 121.9 basis points). The difference of 74.0 basis points between the average values and 55.9 basis points between the median values of bond spread is highly significant in economic terms, especially compared to the average spread of 116 basis points for all bonds (median, 84 basis points). Part of the reason may be that matching on leverage alone does not match well on the other two determinants of default risk.

Although leverage is a principal source of default risk, structural credit risk models suggest that volatility also has a material impact on bond spreads. Thus, to correctly account for default risk, both volatility and leverage should be considered together. Bharath and

\footnotetext{
${ }^{5}$ We confirm this statement by running a Monte-Carlo experiment that shows that the standard errors in parameter estimates are compounded by taking ratios due to Jensen's inequality and can lead to significant variation in the estimated SOA.
}

Table 3 The Magnitude Issue: How Large Is the Predicted Leverage Effect on Bond and CDS Spreads After Controlling for Other Important Determinants of Default Risk?

\begin{tabular}{|c|c|c|c|c|c|c|}
\hline \multirow[b]{2}{*}{ Variables } & \multicolumn{2}{|c|}{$\begin{array}{l}\text { Low predicted } \\
\text { leverage quartile }\end{array}$} & \multicolumn{2}{|c|}{$\begin{array}{l}\text { High predicted } \\
\text { leverage quartile }\end{array}$} & \multirow{2}{*}{$\begin{array}{l}\text { Difference } \\
\text { in means }\end{array}$} & \multirow{2}{*}{$\begin{array}{l}\text { Difference } \\
\text { in medians }\end{array}$} \\
\hline & Mean & Median & Mean & Median & & \\
\hline \multicolumn{7}{|c|}{ Panel A: Matched by leverage $(N=1,810)$} \\
\hline $\begin{array}{l}\text { Predicted } \\
\quad \text { leverage }\end{array}$ & 21.8 & 22.3 & 36.9 & 35.4 & & \\
\hline Leverage & 26.3 & 23.6 & 26.6 & 23.8 & & \\
\hline $\begin{array}{c}\text { Distance to } \\
\text { default }\end{array}$ & 11.9 & 11.8 & 6.5 & 6.6 & & \\
\hline Credit rating & 7.9 & 8.0 & 10.9 & 11.0 & & \\
\hline Bond spread & 81.2 & 66.0 & 155.2 & 121.9 & $74.0^{*}$ & $55.9^{*}$ \\
\hline \multicolumn{7}{|c|}{ Panel B: Matched by distance to default $(N=1,810)$} \\
\hline $\begin{array}{l}\text { Predicted } \\
\quad \text { leverage }\end{array}$ & 21.8 & 22.3 & 36.1 & 35.1 & & \\
\hline $\begin{array}{c}\text { Distance to } \\
\text { default }\end{array}$ & 11.9 & 11.8 & 10.8 & 11.2 & & \\
\hline Leverage & 26.3 & 23.6 & 23.3 & 21.9 & & \\
\hline Credit rating & 7.9 & 8.0 & 9.8 & 10.0 & & \\
\hline Bond spread & 81.2 & 66.0 & 103.0 & 89.1 & $21.8^{*}$ & $23.1^{*}$ \\
\hline \multicolumn{7}{|c|}{ Panel C: Matched by credit rating $(N=1,469)$} \\
\hline $\begin{array}{l}\text { Predicted } \\
\quad \text { leverage }\end{array}$ & 22.0 & 22.5 & 38.6 & 38.6 & & \\
\hline Credit rating & 8.6 & 8.0 & 8.6 & 8.0 & & \\
\hline Leverage & 26.2 & 22.9 & 27.6 & 26.5 & & \\
\hline $\begin{array}{c}\text { Distance to } \\
\text { default }\end{array}$ & 11.8 & 11.7 & 7.7 & 8.2 & & \\
\hline Bond spread & 86.2 & 72.1 & 112.8 & 103.4 & $26.6^{*}$ & $31.3^{*}$ \\
\hline \multicolumn{7}{|c|}{ Panel D: Matched by distance to default and credit rating $(N=1,469)$} \\
\hline $\begin{array}{l}\text { Predicted } \\
\quad \text { leverage }\end{array}$ & 22.0 & 22.5 & 38.1 & 36.5 & & \\
\hline $\begin{array}{c}\text { Distance to } \\
\text { default }\end{array}$ & 11.8 & 11.7 & 9.2 & 9.1 & & \\
\hline Credit rating & 8.6 & 8.0 & 8.6 & 8.0 & & \\
\hline Leverage & 26.2 & 22.9 & 24.7 & 23.7 & & \\
\hline Bond spread & 86.2 & 72.1 & 108.1 & 95.4 & $21.9^{*}$ & 23.3* \\
\hline
\end{tabular}

Notes. We start with the sample of bonds as described in Table 1. We measure the effect of predicted leverage on bond spread after controlling for other variables known to be strongly associated with default (or bankruptcy) risk. These variables are leverage, distance to default, and credit ratings. We do this by controlling for one variable at a time in a matching experiment. Each quarter we arrange all bonds with relevant information into quartiles formed by predicted leverage. For each bond in the bottom quartile of predicted leverage, we then select a bond of a different firm in the top quartile of predicted leverage that is the closest match on leverage in panel $A$, distance to default in panel $\mathrm{B}$, credit rating in panel $\mathrm{C}$, and both distance-to-default and credit rating in panel D. All variables and their units are defined in Appendix C. The bond spreads are expressed in basis points. The significance levels of differences in means and medians are based on a $t$-test and the Wilcoxon signed-rank test.

*Statistically significant at the $1 \%$ level.

Shumway (2008) use the distance to default measure that captures both factors in an option pricing framework. They find that this measure captures the default risk in bonds. Panel B of Table 3 matches firms on distance to default, which implicitly matches them reasonably well on leverage and credit rating. However, 
presumably because of the difference between the predicted leverage of the two subsamples, their bond spreads continue to differ substantially. The difference between average bond spreads in the top and bottom quartiles of predicted leverage equals 21.8 basis points (median, 23.1 basis points).

Panel C of Table 3 does a similar matching by credit rating. Given the discrete nature of credit ratings, the matching is very close in this case. Yet the difference between the average and median bond spreads equals 26.6 and 31.3 basis points in the top and bottom quartiles of predicted leverage, respectively.

Finally, panel D of Table 3 explicitly matches by both the distance to default and credit rating, which implicitly matches by leverage (and volatility) as well. Despite this close matching on all three previously known determinants of default risk, the differences between bond spreads equal 21.9 and 23.3 basis points, not much different from panels $B$ and $C$. This is likely to be the best estimate of the incremental effect of predicted leverage in a matched-bond setting. An interquartile spread of $36.5-22.5=14.0 \%$ in predicted leverage is associated with an incremental bond spread of 22 or 23 basis points. Given a median time to maturity of six years from Table 1, which may translate into bond duration of five years, this difference in spreads corresponds to a difference in bond prices of the order of $1.10 \%$. The combined results of Tables 2 and 3 thus provide strong evidence that higher predicted leverage is associated with higher default risk of corporate bonds.

\subsection{Estimating SOA in the Aggregate Sample of CDS Contracts}

We now estimate SOA toward the predicted leverage, or $\lambda$, using a nonlinear GMM approach and combining CDS contracts of multiple maturities. We estimate the model summarized by the system of Equations (8) in §2.1. A question arises as to which CDS contracts should be included in this system. We argue that it should be one-year, two-year, and five-year CDS contracts for several reasons. First, although the five-year CDS contract is the most liquid and the most investigated CDS contract in previous literature, one-year and two-year CDS contracts are also fairly liquid. Second, we prefer to limit CDS maturity to five years because the expected gap between leverage and predicted leverage after five years is quite small (onethird of the original gap if $\lambda=0.20$ and one-fourth if $\lambda=0.25)$. Previous literature argues that due to transaction costs, the expected leverage adjustment after the gap reduces to that level is quite small (Fischer et al. 1989, Graham and Harvey 2001). Third, using one-year, two-year, and five-year CDS contracts effectively spans the short and long ends of the maturity spectrum. For expositional reasons, however, we present our main results relating to SOA with only one-year and five-year CDS contracts in Tables 4, 6, and 7. Later in Table 8 we show that the $\lambda$ values estimated using other combinations of one-year, twoyear, and five-year CDS contracts are similar to the $\lambda$ values reported for the combination of one-year and five-year CDS contracts.

Our sample includes 5,828 firm-quarters for which the data on both one-year and five-year CDS spreads are available. The results are shown in Table 4 . We find a reasonable similarity between the coefficients of two firm-specific variables (historical volatility and $\log$ assets) and five macroeconomic variables (Treasury bond yield, term spread, default spread, market volatility, and market return) for five-year CDS spreads estimated using the GMM in Table 4 and the OLS in Table 2. Furthermore, we find reasonable correspondence between the coefficients of control variables for one-year and five-year CDS spreads within Table 4. Finally, the coefficient of effective leverage (measured by expected average leverage) for fiveyear CDS spreads equals 4.50, which is 2.5 times the coefficient of effective leverage for one-year CDS spreads. This should be expected since longer-term CDS spreads are more sensitive to firm leverage due to the put option feature. Together these observations add credibility to our GMM estimation procedure.

Table 4 focuses on the implied SOA, which we estimate to be 0.259 in the aggregate sample of CDS spreads. Notice we have actually estimated a riskadjusted value of SOA implicit in the prices of credit instruments. This is no different from implied stock price distributions from option prices (Rubinstein 1994), implied financial distress costs from bond spreads (Almeida and Philippon 2007), or implied default probabilities and recovery rates from CDS spreads (Pan and Singleton 2008), all of which are risk-adjusted estimates of the corresponding true values. However, there is no reason to believe that in our case the implied SOA is systematically higher or lower than the true SOA, or $\lambda^{*}{ }^{6}$

Our estimate of implied SOA is roughly in the middle of time-series estimates of SOA from previous literature. It is higher than estimates from Fama and French (2002), Kayhan and Titman (2007), and Huang

\footnotetext{
${ }^{6}$ Consider the situation where leverage is below predicted leverage, and suppose that buyers and sellers of credit risk agree on $\lambda^{*}$. A risk-averse buyer of credit insurance may be afraid that leverage will not adjust quickly enough, whereas a risk-averse seller may be afraid that it will adjust too quickly. The former would assess $\lambda<\lambda^{*}$, and the latter would assess $\lambda>\lambda^{*}$. If we have no reason to believe that the buyers are systematically more or less risk-averse than the sellers, then we would expect $\lambda=\lambda^{*}$ to prevail in equilibrium. A similar situation is expected when leverage is above predicted leverage, except that in this case the buyers and sellers are afraid for the opposite reasons.
} 
Implied Speed of Leverage Adjustment $(\lambda)$ in the Aggregate Sample Using Nonlinear GMM

Estimated $\lambda$ from one-year and five-year CDS contracts

\begin{tabular}{lrrr}
\hline Independent variable & Coefficient $(t$-statistic) & Independent variable & Coefficient $(t$-statistic) \\
\hline$\lambda$ (risk-neutral speed of leverage adjustment) & $0.259(14.17)$ & & \\
$c_{1, \text { efflev }}$ & $1.80(16.68)$ & $c_{5, \text { efflev }}$ & $4.50(25.47)$ \\
$c_{1, \text { vol }}$ & $5.51(25.67)$ & $c_{5, \text { vol }}$ & $7.00(32.10)$ \\
$c_{1, \text { logast }}$ & $-2.97(-2.48)$ & $c_{5, \text { logast }}$ & $-8.40(-5.90)$ \\
$c_{1, \text { rf }}$ & $-0.02(-0.61)$ & $c_{5, \text { rf }}$ & $-0.14(-3.29)$ \\
$c_{1, \text { trmsprd }}$ & $0.02(1.21)$ & $c_{5, \text { trmsprd }}$ & $-0.29(-13.86)$ \\
$c_{1, \text { defsprd }}$ & $-0.32(-3.29)$ & $c_{5, \text { defsprd }}$ & $-0.58(-5.30)$ \\
$c_{1, \text { vix }}$ & $1.24(3.66)$ & $c_{5, \text { vix }}$ & $2.77(7.05)$ \\
$c_{1, \text { mkrret }}$ & $0.20(1.54)$ & $c_{5, \text { mktret }}$ & $0.86(6.17)$ \\
$c_{1, \text { const }}$ & $-113.05(-5.24)$ & $c_{5, \text { const }}$ & $-66.56(-2.72)$ \\
Adjusted $R^{2}$ & 0.440 & Adjusted $R^{2}$ & 0.494 \\
Observations & 5,828 & Observations & 5,828
\end{tabular}

Notes. The CDS sample is described in Table 1. In this table we estimate the implied speed of adjustment $(\lambda)$ of current leverage toward the predicted leverage using one-year and five-year CDS contracts. The partial adjustment model that describes this movement is given as

$$
E_{0}\left(\operatorname{Lev}_{1}\right)=\lambda \cdot P \operatorname{Lev}_{1}+(1-\lambda) \cdot \operatorname{Lev}_{0}
$$

where $L e v_{0}$ denotes the leverage during year 0 , and PLev $v_{1}$ denotes the predicted leverage during year 1. Section 2.1.1 shows that from this the expected average leverage over the $t$ years starting at time points $0,1,2, \ldots, t-1$ can be written as

$$
E_{0}\left(\overline{\operatorname{Lev}}_{0, t-1}\right)=\frac{1-(1-\lambda)^{t}}{\lambda t} \operatorname{LeV}_{0}+\left(1-\frac{1-(1-\lambda)^{t}}{\lambda t}\right) P L e V_{1}
$$

We reason that the CDS spread depends on the effective leverage (as measured by the expected average leverage) during its term to maturity in addition to the control variables from previous literature listed in Table 2. Given the values of all other parameters, we estimate the implied $\lambda$ from the following system of equations using the nonlinear GMM approach as follows:

$$
\begin{aligned}
& \operatorname{CDS}_{t_{1}}=c_{1, \text { efflev }} \cdot E_{0}\left(\overline{\operatorname{Lev}}_{0, t_{1}-1}\right)+c_{1, \text { vol }} \cdot \operatorname{VOL}+c_{1, \text { logast }} \cdot \operatorname{LOGAST}+c_{1, \text { rf }} \cdot R F+c_{1, \text { trmsprd }} \cdot \operatorname{TRMSPRD}+c_{1, \text { defsprd }} \cdot \text { DEFSPRD }+c_{1, \text { vix }} \cdot \text { VIX } \\
& +c_{1, \text { mktret }} \cdot \operatorname{MKTRET}+c_{1, \text { const }}+\epsilon_{t_{1}} \text {; } \\
& \operatorname{CDS}_{t_{2}}=c_{2, \text { efflev }} \cdot E_{0}\left(\overline{\operatorname{Lev}}_{0, t_{2}-1}\right)+c_{2, \text { vol }} \cdot V O L+c_{2, \text { logast }} \cdot L O G A S T+c_{2, \text { rf }} \cdot R F+c_{2, \text { trmsprd }} \cdot T R M S P R D+c_{2, \text { defsprd }} \cdot \text { DEFSPRD }+c_{2, \text { vix }} \cdot V I X \\
& +c_{2, \text { mktret }} \cdot \operatorname{MKTRET}+c_{2, \text { const }}+\epsilon_{t_{2}}
\end{aligned}
$$

$C D S_{t_{1}}$ and $C D S_{t_{2}}$ denote the CDS spreads for $t_{1}$ and $t_{2}$ years of coverage; VOL and LOGAST denote the historic volatility and log assets of the firm; and $R F$, TRMSPRD, DEFSPRD, VIX, and MKTRET denote the 10-year Treasury bond yield, term spread, default spread, market volatility, and market return, respectively. Appendix $C$ defines these variables, and Appendix D describes the calculation of predicted leverage that enters Equation (T4.2). We use model (D.1), which includes industry and year fixed effects, but excludes firm fixed effects. For parsimony of presentation, we show the implied $\lambda$ calculated from one-year and five-year CDS contracts in this table, so $t_{1}=1$ and $t_{2}=5$. Later in Table 8 we show similar parameters estimated from a system of two-year and five-year CDS contracts, and another system of one-year, two-year, and five-year CDS contracts. (Using a system of equations to span a fair part of the term structure of CDS maturities gives better estimates of implied parameters as discussed in $\S 4$.3.) The $t$-statistics are reported in parentheses. The $t$-statistics greater than $2.58,1.96$, and 1.64 are statistically significant at the $1 \%, 5 \%$, and $10 \%$ levels, respectively.

and Ritter (2009); comparable to the SOA estimates provided by Lemmon et al. (2008); and lower than estimates from Flannery and Rangan (2006) and Frank and Goyal (2007). The last three studies include firm or CEO fixed effects in the predicted leverage model. Our base model of predicted leverage in Table 4 includes industry and year fixed effects, but no firm fixed effects. Below we present additional evidence on whether or not to include firm fixed effects in the predicted leverage model. Given our implied SOA estimates, a firm is expected to reduce $25.9 \%$ of its original gap between leverage and predicted leverage after 1 year, $\left(1-(1-0.259)^{3}\right)=59.3 \%$ after 3 years, $77.7 \%$ times after 5 years, and $95.0 \%$ after 10 years. This is evidence of fairly rapid adjustment of lever- age toward the predicted leverage. Our evidence thus differs from the evidence of Fama and French (2002), who conclude that the mean reversion of leverage toward predicted leverage is at a snail's pace.

\section{Alternate Theories of Capital Structure and Speed of Leverage Adjustment}

Section 2 showed that our model of predicted leverage has some elements of all three theories of capital structure-pecking order, market timing, and tradeoff theories-embedded in it. Section 4 showed that firms move toward predicted leverage at a fairly rapid speed, so all theories may contribute in part to 
this movement. In this section we provide stronger evidence that each theory also separately explains the capital structure by using an alternate technique that analyzes the evidence on SOA within partitions formed by a key implication of each theory.

The key factor in pecking order theory proposed by Donaldson (1961) and Myers (1984) is whether the firm has a financial deficit or surplus. If the firm has a deficit, it issues the safest security first, that is, debt before equity. Alternately, if the firm has a surplus, it pays down debt rather than repurchase equity. The key factor in market timing theory proposed by Baker and Wurgler (2002) is whether the equity is undervalued or overvalued. If the firm has a deficit, it issues equity when insiders perceive it to be overvalued and debt otherwise. Alternately, if the firm has a surplus, it repurchases equity when perceived to be undervalued and debt otherwise. Finally, the key factor in trade-off theory is whether leverage is below or above the target or predicted leverage. If below predicted leverage, the firm issues debt if it faces deficit or repurchases equity if it faces surplus. Alternately, if above predicted leverage, the firm issues equity if it faces deficit and repurchases debt if it faces surplus.

Table 5 partitions the sample based on these key factors. The first four partitions $\mathrm{P} 1$ to $\mathrm{P} 4$ consider the combined implications of pecking order and trade-off theories, the next four partitions M1 to M4 consider market timing and trade-off theories, and the last eight partitions PM1 to PM8 consider all three theories. The detailed implications are best understood by looking at the table. The last column summarizes the bottom-line implications for the speed of adjustment toward predicted leverage by combining all theories. For an illustration, consider partition PM1, where the firm has a financial deficit, its equity is undervalued, and the leverage is above its target or predicted leverage. Both pecking order and market timing theories imply that the firm will issue debt, which is opposite to what trade-off theory implies, that the firm will issue equity. Thus, the speed of adjustment in this

Table 5 Interactions of the Three Theories of Capital Structure and Their Implications for Implied Speed of Leverage Adjustment $(\lambda)$

\begin{tabular}{|c|c|c|c|c|c|c|c|}
\hline \multirow[b]{2}{*}{$\begin{array}{l}\text { Partition } \\
\text { number }\end{array}$} & \multicolumn{3}{|c|}{ Key factors } & \multicolumn{3}{|c|}{ Implications of the three theories of capital structure } & \multirow[b]{2}{*}{$\begin{array}{l}\text { Implied speed } \\
\text { of adjustment } \\
\text { toward PLev } \\
\text { combining all } \\
\text { theories }\end{array}$} \\
\hline & $\begin{array}{c}\text { Financing } \\
\text { deficit or } \\
\text { surplus }\end{array}$ & $\begin{array}{c}\text { Undervalued } \\
\text { or overvalued } \\
\text { equity }\end{array}$ & $\begin{array}{l}\text { Leverage } \\
\text { deviation } \\
\text { from } \\
\text { predicted }\end{array}$ & Pecking order & Market timing & Trade-off & \\
\hline P1 & Deficit & & Lev $>$ PLev & Issue debt & & Issue equity & Low \\
\hline $\mathrm{P} 2$ & Deficit & & Lev $<$ PLev & Issue debt & & Issue debt & High \\
\hline P3 & Surplus & & Lev $>$ PLev & Repurchase debt & & Repurchase debt & High \\
\hline P4 & Surplus & & Lev $<$ PLev & Repurchase debt & & Repurchase equity & Low \\
\hline M1 & & Undervalued & Lev $>$ PLev & & $\begin{array}{l}\text { Issue debt or } \\
\text { repurchase equity }\end{array}$ & $\begin{array}{l}\text { Issue equity or } \\
\text { repurchase debt }\end{array}$ & Low \\
\hline M2 & & Undervalued & Lev $<$ PLev & & $\begin{array}{l}\text { Issue debt or } \\
\text { repurchase equity }\end{array}$ & $\begin{array}{l}\text { Issue debt or } \\
\text { repurchase equity }\end{array}$ & High \\
\hline M3 & & Overvalued & Lev $>$ PLev & & $\begin{array}{l}\text { Issue equity or } \\
\text { repurchase debt }\end{array}$ & $\begin{array}{l}\text { Issue equity or } \\
\text { repurchase debt }\end{array}$ & High \\
\hline M4 & & Overvalued & Lev $<$ PLev & & $\begin{array}{l}\text { Issue equity or } \\
\text { repurchase debt }\end{array}$ & $\begin{array}{l}\text { Issue debt or } \\
\text { repurchase equity }\end{array}$ & Low \\
\hline PM1 & Deficit & Undervalued & Lev $>$ PLeV & Issue debt & Issue debt & Issue equity & Very low \\
\hline PM2 & Deficit & Undervalued & Lev $<$ PLev & Issue debt & Issue debt & Issue debt & Very high \\
\hline PM3 & Deficit & Overvalued & Lev $>$ PLev & Issue debt & Issue equity & Issue equity & Medium \\
\hline PM4 & Deficit & Overvalued & Lev $<$ PLev & Issue debt & Issue equity & Issue debt & Medium \\
\hline PM5 & Surplus & Undervalued & Lev $>$ PLev & Repurchase debt & Repurchase equity & Repurchase debt & Medium \\
\hline PM6 & Surplus & Undervalued & Lev $<P$ Lev & Repurchase debt & Repurchase equity & Repurchase equity & Medium \\
\hline PM7 & Surplus & Overvalued & Lev $>$ PLeV & Repurchase debt & Repurchase debt & Repurchase debt & Very high \\
\hline PM8 & Surplus & Overvalued & Lev $<$ PLev & Repurchase debt & Repurchase debt & Repurchase equity & Very low \\
\hline
\end{tabular}

Notes. The three theories of capital structure include the pecking order theory, the market timing theory, and the trade-off theory. The key factor in pecking order theory proposed by Donaldson (1961) and Myers (1984) is whether the firm has a financial deficit or surplus. If the firm has a deficit, it issues the safest security first, that is, debt before equity. Alternately, if the firm has a surplus, it pays down debt rather than repurchase equity. The key factor in market timing theory proposed by Baker and Wurgler (2002) is whether the equity is undervalued or overvalued. If the firm has a deficit, it issues equity when insiders perceive it to be overvalued and debt otherwise. Alternately, if the firm has a surplus, it repurchases equity when perceived to be undervalued and debt otherwise. Finally, the key factor in trade-off theory is whether leverage is below or above the target leverage, which we measure by the predicted leverage. If below predicted leverage, then the firm issues debt if it faces deficit or repurchases equity if it faces surplus. Alternately, if above predicted leverage, then the firm issues equity if it faces deficit and repurchases debt if it faces surplus. This table shows the combined results of these three theories of capital structure within several partitions formed by relevant firm characteristics and derives implications for the speed of adjustment of leverage toward the predicted leverage. Lev and PLev are acronyms for (current) leverage and predicted leverage. 
partition will be very low if investors' expectations of leverage adjustments are influenced by all three theories.

Many partitions in Table 5 have similar implications for speed of adjustment. For example, in P1 the firm faces a financial deficit, and its leverage is above predicted leverage. Pecking order theory implies that the firm will issue debt, whereas trade-off theory implies that it will issue equity; thus we expect low speed of adjustment over the term to maturity. In P4, the key factors are the opposite. The firm faces a financing surplus and its leverage is below predicted leverage, so pecking order theory implies that the firm will repurchase debt, whereas trade-off theory implies that it will repurchase equity. Not knowing the relative strengths of the implications of pecking order and trade-off theories, the extent of deficit or surplus versus the deviation from predicted leverage, or the transaction costs incurred in issues and repurchases of debt and equity, we join partitions $\mathrm{P} 1$ and $\mathrm{P} 4$ and expect a common low implied SOA toward predicted leverage. Using similar arguments, we also aggregate P2 and P3, M1 and M4, M2 and M3, PM1 and PM8, PM3 to PM6, and PM2 and PM7. This process leads to seven aggregated partitions, which we simply refer to as partitions in the subsequent analysis.

We measure financial deficit as dividend plus investments plus change in working capital minus cash flow, following Frank and Goyal (2003). A negative financial deficit is surplus. We measure equity undervaluation or overvaluation by prior-year excess return calculated as the cumulative stock return over a 252-day period ending one day before the earnings announcement date minus the cumulative market return. A negative excess return is commonly interpreted in literature as equity undervaluation, and a positive return as overvaluation (Loughran and Ritter 1995). This is an alternate measure of overvaluation relative to market-to-book ratio that is included in the predicted leverage model and may reduce the concern that the latter is simultaneously a good measure of growth opportunities.

Table 6 shows a GMM analysis of the system of Equations (8) applied to one-year and five-year CDS contracts within the seven partitions described in Table 5. Despite smaller sample sizes within any partition ranging between 1,268 and 3,117, we observe a reasonable consistency of coefficients for one-year and five-year contracts within a partition and across partitions for either contract. Models (6.1) and (6.2) show that the SOA equals 0.173 and 0.339 across the two partitions formed by the intersection of pecking order and trade-off theories. The difference in SOA values of 0.166 is in the expected direction and significant at the $1 \%$ level. Models (6.3) and (6.4) next show that the SOA equals 0.231 and 0.315 across partitions formed by the intersection of market timing and trade-off theories, and the difference of 0.084 is in the expected direction and also significant at the $10 \%$ level.

Finally, models (6.5), (6.6), and (6.7) test the combined implications of all three theories. The SOA equals $0.127,0.299$, and 0.363 across these three partitions, following the expected trend. The difference between the first and second partitions equals 0.172 and is significant at the $1 \%$ confidence level, but the difference between the second and third partitions equals a statistically insignificant 0.064 . To understand the economic significance of the differences, SOA values of $0.127,0.299$, and 0.363 translate into half-lives of leverage adjustment of 5.10, 1.95, and 1.54 years. We also note that the difference between implied SOA in models (6.5) and (6.7) equals 0.236, which is comparable to the sum of differences of 0.166 from models (6.1) and (6.2) and 0.084 from models (6.3) and (6.4). This suggests that the effects of pecking order and market timing theories on implied SOA are more or less independent of each other as one may expect.

Despite the smaller subsample sizes resulting from partitioning the sample, the empirical evidence in Table 6 follows the expected pattern in Table 5. It is also interesting that although we have formed partitions by a simple bifurcation of the aggregate sample using the directional implication of each theory, the implied SOA is positive in all cases. ${ }^{7}$ This finding suggests that in the long run leverage moves toward the predicted leverage as modeled, even though in the short run pecking order and market timing considerations might take it in the opposite direction. In addition, it suggests that financing deficit or surplus and equity undervaluation or overvaluation do not persist for very long.

In summary, our evidence suggests that the three prominent theories of capital structure all play a significant role in the capital structure decisions of firms. Using an entirely different methodology that surveys investors' expectations of leverage changes implied by credit spreads, our evidence complements the evidence of Huang and Ritter (2009, p. 238), who conclude, "No single theory of capital structure is capable of explaining all of the time-series and cross-sectional patterns that have been documented."

\footnotetext{
${ }^{7}$ Theoretically, a negative speed of adjustment is possible, at least over some horizon, indicating sustained changes in leverage away from the predicted leverage. This may occur if one forms more extreme partitions using the magnitudes of financial deficit or surplus and stock undervaluation or overvaluation. Alternately, a negative speed of adjustment is also possible if there is a great deal of persistence in these key factors underlying the pecking order and market timing theories.
} 
Table 6

Implied Speed of Leverage Adjustment $(\lambda)$ Using GMM in Partitions Formed by the Interactions of the Three Theories of Capital Structure

\begin{tabular}{|c|c|c|c|c|c|c|c|}
\hline \multirow{2}{*}{$\begin{array}{l}\text { Partitions formed by } \rightarrow \\
\text { Partition numbers from Table } 5 \rightarrow\end{array}$} & \multicolumn{2}{|c|}{ Pecking order and trade-off } & \multicolumn{2}{|c|}{ Market timing and trade-off } & \multicolumn{3}{|c|}{ Pecking order, market timing, and trade-off } \\
\hline & P1, P4 & P2, P3 & M1, M4 & M2, M3 & PM1, PM8 & PM3, PM4, PM5, PM6 & PM2, PM7 \\
\hline Predicted speed of leverage adjustment $(\lambda) \rightarrow$ & Low & High & Low & High & Very low & Medium & Very high \\
\hline Variables $\downarrow$ & $(6.1)$ & $(6.2)$ & $(6.3)$ & $(6.4)$ & $(6.5)$ & $(6.6)$ & $(6.7)$ \\
\hline$\lambda$ (risk-neutral speed of leverage adjustment) & $0.173^{*}$ & $0.339 *$ & $0.231 *$ & $0.315^{*}$ & $0.127^{*}$ & $0.299 *$ & $0.363^{*}$ \\
\hline$c_{1, \text { efflev }}$ & $2.06^{*}$ & $1.44^{*}$ & $2.08^{*}$ & $1.28^{*}$ & $2.84^{*}$ & $1.38^{*}$ & $1.21^{*}$ \\
\hline$c_{1, \text { vol }}$ & $5.16^{*}$ & $5.53^{*}$ & $5.10^{*}$ & $5.84^{*}$ & $5.04^{*}$ & $5.30^{*}$ & $6.05^{*}$ \\
\hline$c_{1, \text { logast }}$ & $-2.09^{*}$ & $-4.03^{* * *}$ & $-4.07^{* *}$ & -1.93 & -0.87 & $-4.65^{*}$ & -1.32 \\
\hline$c_{1, r f}$ & -0.06 & 0.01 & $-0.08^{* * *}$ & 0.04 & $-0.11^{* * *}$ & -0.02 & 0.05 \\
\hline$c_{1, \text { trmsprd }}$ & 0.18 & 0.04 & 0.02 & 0.04 & $0.07^{* * *}$ & -0.01 & $0.10^{* *}$ \\
\hline$c_{1, \text { defsprd }}$ & $-0.31^{* *}$ & $-0.29^{* * *}$ & $-0.35^{* *}$ & $-0.27^{* * *}$ & -0.30 & $-0.36^{* *}$ & -0.27 \\
\hline$c_{1, \text { vix }}$ & $0.99^{* *}$ & $1.13^{* *}$ & $1.39^{*}$ & $0.94^{* * *}$ & 0.26 & $2.05^{*}$ & -0.05 \\
\hline$c_{1, m k t r e t}$ & $0.30^{* * *}$ & -0.05 & 0.10 & 0.14 & 0.12 & 0.23 & -0.26 \\
\hline$c_{1, \text { const }}$ & $-98.00^{*}$ & $-109.64^{*}$ & $-75.62^{*}$ & $-145.46^{*}$ & $-98.41^{*}$ & $-91.69 *$ & $-140.23^{* *}$ \\
\hline Adjusted $R^{2}$ & 0.457 & 0.425 & 0.459 & 0.429 & 0.488 & 0.441 & 0.412 \\
\hline Observations & 3,012 & 2,807 & 3,117 & 2,702 & 1,578 & 2,964 & 1,268 \\
\hline$C_{5, \text { efflev }}$ & $4.39^{*}$ & $4.34^{*}$ & $5.04^{*}$ & $3.66^{*}$ & $5.56^{*}$ & $3.94^{*}$ & $3.89 *$ \\
\hline$C_{5, \text { vol }}$ & $6.51^{*}$ & $7.19^{*}$ & $6.63^{*}$ & $7.37^{*}$ & $6.51^{*}$ & $6.70^{*}$ & $7.82^{*}$ \\
\hline$C_{5, \text { logast }}$ & $-7.73^{*}$ & $-9.05^{*}$ & $-10.48^{*}$ & $-6.25^{*}$ & $-5.42^{* *}$ & $-11.71^{*}$ & -3.19 \\
\hline$C_{5, r f}$ & $-0.19^{*}$ & -0.09 & $-0.19^{*}$ & -0.07 & $-0.24^{*}$ & $-0.14^{* *}$ & -0.03 \\
\hline$C_{5, \text { trmsprd }}$ & $-0.27^{*}$ & $-0.29^{*}$ & $-0.28^{*}$ & $-0.27^{*}$ & $-0.22^{*}$ & $-0.31^{*}$ & $-0.25^{*}$ \\
\hline$C_{5, \text { defsprd }}$ & $-0.57^{*}$ & $-0.57^{*}$ & $-0.50^{*}$ & $-0.67^{*}$ & $-0.46^{* * *}$ & $-0.62^{*}$ & $-0.72^{*}$ \\
\hline$C_{5, \text { vix }}$ & $2.72^{*}$ & $2.55^{*}$ & $2.75^{*}$ & $2.66^{*}$ & $1.93^{* *}$ & $3.21^{*}$ & $1.99^{* *}$ \\
\hline$C_{5, m k t r e t}$ & $0.89^{*}$ & $0.66^{*}$ & $0.89^{*}$ & $0.85^{*}$ & $0.63^{* *}$ & $0.84^{*}$ & $0.54^{* * *}$ \\
\hline$C_{5, \text { const }}$ & -33.67 & -77.51 & -36.45 & $-95.26^{* *}$ & -62.27 & -15.03 & $-138.50^{* *}$ \\
\hline Adjusted $R^{2}$ & 0.494 & 0.495 & 0.512 & 0.484 & 0.531 & 0.492 & 0.486 \\
\hline Observations & 3,016 & 2,807 & 3,117 & 2,702 & 1,578 & 2,964 & 1,268 \\
\hline
\end{tabular}

Notes. The CDS sample is described in Table 1, and the methodology of calculating implied speed of leverage adjustment ( $\lambda$ ) is described in Table 4. We use the combination of one-year and five-year CDS contracts to calculate implied $\lambda$ everywhere in this table. The partitions formed by the interactions of the three theories of capital structure are described in Table 5. These theories are the pecking order theory, the market timing theory, and (a modified form of) the trade-off theory. We combine the partitions listed in Table 5 as noted in the panel headings of this table. Appendix $C$ defines the variables analyzed. In particular, it mentions that financing deficit is measured as dividend plus investments plus change in working capital minus cash flow using quarterly data, and undervaluation/overvaluation is measured by prior-year excess returns defined as difference between stock return and market return over a 250-day period ending before the quarterly earnings announcement date. The aggregate sample is divided into two halves based on each of whether there is a deficit or a surplus for pecking order partitions, whether the prior-year excess return is negative (undervalued) or positive (overvalued) for market timing partitions, and whether (current) leverage is above or below predicted leverage for trade-off partitions. Appendix D describes model (D.1) used to estimate the predicted leverage. This model includes year and industry fixed effects. We report two-way clustered $t$-statistics that adjust for clustering at the firm and the calendar quarter levels in parentheses. The difference between $\lambda$ values across models (6.1) and (6.2) is significant at the $1 \%$ level, across models (6.3) and (6.4) significant at the $10 \%$ level, across models (6.5) and (6.6) significant at the $1 \%$ level, across models (6.5) and (6.7) significant at the $1 \%$ level, and across models (6.6) and (6.7) insignificant.

*Statistically significant at the $1 \%$ level; ** statistically significant at the $5 \%$ level; *** statistically significant at the $10 \%$ level.

\section{Using Speed of Adjustment to Test Alternate Measures of Predicted Leverage: The Role of Firm Fixed Effects and Initial Leverage}

In the introductory section we discussed the controversy surrounding the inclusion of firm fixed effects in the predicted leverage model. Flannery and Rangan (2006) and Lemmon et al. (2008) argue that firm fixed effects capture firm-specific heterogeneity not captured by the included firm characteristics and lead to more precise estimates of predicted leverage. In support of this argument they show that the inclusion of firm fixed effects explains a greater proportion of the variability in leverage values and leads to a higher SOA toward the presumed more precise estimates of predicted leverage. However, others have argued that the inclusion of firm fixed effects also creates a look-ahead bias with the traditional timeseries methodology and may artificially increase SOA as leverage naturally reverts to its mean value based in part on the future leverage values. In comparison, our methodology examines investor expectations at a given point in time and does not suffer from this lookahead bias. In fact, the inclusion of future information that is not a part of investors' expectations should act like a noise with our methodology and reduce the SOA toward a noisy predicted leverage.

Table 7 presents the evidence to back our conjectures using the aggregate sample. We start with our base model of predicted leverage that includes industry and year fixed effects and gives an SOA of 0.259. 
Elkamhi, Pungaliya, and Vijh: What Do Credit Markets Tell Us About the Speed of Leverage Adjustment?

Table 7 Variations on the Model of Estimating Predicted Leverage and Implied Speed of Leverage Adjustment $(\lambda)$ in the Aggregate Sample of CDS Contracts Using Nonlinear GMM

Panel A: Effect of adding noise to predicted leverage estimated using industry and year fixed effects

\begin{tabular}{llllllll}
\hline Proportional noise & 0.00 & 0.25 & 0.50 & 0.75 & 1.00 & 1.50 & 2.00 \\
Implied speed of leverage adjustment $(\lambda)$ & 0.259 & 0.244 & 0.208 & 0.162 & 0.123 & 0.076 & 0.049 \\
\hline
\end{tabular}

Panel B: Predicted leverage model and speed of leverage adjustment $(\lambda)$

\begin{tabular}{|c|c|c|c|}
\hline Row & Model & $\lambda$ & Increase in $\lambda$ \\
\hline 1 & (D.1), which includes industry and year fixed effects but excludes firm fixed effects & 0.259 & \\
\hline 2 & (D.2), which includes year fixed effects but excludes industry or firm fixed effects & 0.196 & $-0.063^{\dagger}$ \\
\hline 3 & $\begin{array}{l}\text { (D.3), which includes year and firm fixed effects but excludes industry fixed effects, also includes full panel of data from } 1967 \text { to } \\
\text { 2007, which captures firm-specific heterogeneity but creates a look-ahead bias }\end{array}$ & 0.170 & $-0.026^{\ddagger}$ \\
\hline 4 & Variation on model (D.3) in row 3: Includes a shorter panel of data from 1997 to 2007, which increases the look-ahead bias & 0.132 & $-0.064^{\ddagger}$ \\
\hline 5 & $\begin{array}{l}\text { Variation on model (D.3) in row 3: For each CDS observation includes only a subset of observations from } 1967 \text { to the year before } \\
\text { the observation, which eliminates the look-ahead bias but also shortens the panel of data as in row } 4\end{array}$ & 0.170 & $-0.026^{\ddagger}$ \\
\hline 6 & Initial firm leverage as an estimate of predicted leverage & 0.045 & $-0.214^{\dagger}$ \\
\hline
\end{tabular}

Notes. The sample of CDS contracts is described in Table 1, and the methodology of calculating implied speed of leverage adjustment $(\lambda)$ is described in Table 4. We use the combination of one-year and five-year CDS contracts to calculate implied $\lambda$ everywhere in this table. Panel A examines how implied $\lambda$ is affected by adding noise to the predicted leverage estimated using model (D.1) in Appendix D. This model includes industry and year fixed effects, but excludes firm fixed effects. Noise in this panel is a normal random variable with a standard deviation equal to a multiple of the cross-sectional standard deviation of predicted leverage (which equals 6.58\%). Panel B examines implied $\lambda$ when predicted leverage is estimated using alternate models. Two of these alternate models are presented in full detail as models (D.2) and (D.3) in Appendix D, but the rest are outlined here, although the details are omitted for brevity. Model (D.2) includes only year fixed effects, and model (D.3) includes both year and firm fixed effects. (Notice that firm fixed effects encapsulate industry fixed effects, so both cannot both be added in the same model.) Both models exclude industry fixed effects and include the full panel of data from 1962 to 2007 . Industry fixed effects are based on Fama and French (1997) 48-industry classification.

${ }^{\dagger}$ Relative to model (D.1) in row 1.

$\ddagger$ Relative to model (D.2) in row 2.

Panel A first shows how the addition of a white noise to the corresponding predicted leverage values reduces SOA. This noise is a normal random variable with a standard deviation equal to a multiple of the standard deviation of predicted leverage in the same aggregate sample (which equals $6.58 \%$ ). With multiples of $0.50,1.00$, and 2.00, the SOA reduces to 0.208 , 0.123 , and 0.049 (a decrease of $0.051,0.136$, and 0.210 ). These estimates serve as a benchmark in understanding the effects of model specification changes that follow next.

Row 1 in panel B shows the SOA estimates from the base model, and row 2 shows the SOA estimates with predicted leverage estimated using model (D.2). This model deletes industry fixed effects, but retains all other variables in the base model. The implied SOA drops to 0.196 , a decrease of 0.063 in absolute terms and one-fourth in relative terms. From panel A we estimate that this effect is equivalent to adding a noise with a standard deviation equal to 0.6 times the standard deviation of predicted leverage in the aggregate sample. Row 3 in panel B is important; it shows that further inclusion of firm fixed effects as in the predicted leverage model (D.3) decreases the SOA to 0.170 , a further decrease of 0.026 from row 2 and a cumulative decrease of 0.089 from the base model. This suggests that the inclusion of firm fixed effects does not refine investors' expectations about predicted leverage values; instead it adds noise.

To further examine the role of firm fixed effects, row 4 uses a shorter panel of data from 1997 to
2007 instead of the full panel from 1967 to 2007 in row 3. This should increase the look-ahead bias in our CDS sample that spans 2000 to 2007 (Woolridge 2002). Consistent with this conjecture, we find that SOA decreases to 0.132 . Row 5 next uses only a subset of the full panel of observations, from 1967 to the year before an observation, which eliminates the lookahead bias, but also shortens the panel. This increases the SOA back to 0.170 , the same as in row 3. Coincidentally, this estimate is very similar to the SOA estimate of 0.169 using only historical panel data in Hovakimian and Li (2011).

The combined evidence suggests that the SOAdecreasing effects of the look-ahead bias dominate the SOA-increasing effects of capturing unobserved firm-specific heterogeneity. Thus, the SOA estimates of studies employing firm fixed effects and using the traditional time-series methodology are likely to be overstated.

Finally, row 6 of panel B tests another hypothesis from previous literature. Lemmon et al. (2008) also suggest that there is considerable persistence in firm leverage. They argue that a firm's leverage goes back to the beginning, in other words, the firm's initial leverage at the time of initial public offering is a good proxy for its predicted leverage 20 years later. However, DeAngelo and Roll (2011) document a wide variation in leverage values over any individual firm's history. Row 6 shows that using initial leverage as a proxy for predicted leverage gives an SOA of 0.045 
with our methodology, a steep reduction from the base model value of 0.259 . Consistent with DeAngelo and Roll (2011), this evidence suggests that initial leverage from the first time a firm appears on Compustat is not a good proxy for predicted leverage in later years in the minds of credit market investors.

\section{Robustness Tests and Miscellaneous Results}

\subsection{Using Historical Asset Volatility and Implied Equity Volatility in Place of Historical Equity Volatility}

Merton's (1974) model relates bond prices and spreads to the asset volatility of the firm. Specifically, the equity of a firm is viewed as an option on the firm's assets as follows:

$$
E=V N\left(d_{1}\right)+e^{-r T} F N\left(d_{2}\right) .
$$

Here $E$ is the market value of equity, $V$ is the market value of firm, $F$ is the face value of debt, $r$ is the risk-free interest rate, $T$ is the time to maturity, $N(z)$ is the cumulative standard normal distribution function, $d_{1}=\left(\ln (V / F)+\left(r+0.5 \sigma_{V}^{2}\right) T\right) /\left(\sigma_{V} \sqrt{T}\right)$, $d_{2}=d_{1}-\sigma_{V} \sqrt{T}$, and finally, $\sigma_{V}$ is the asset volatility. Furthermore, the asset volatility $\sigma_{V}$ and the equity volatility $\sigma_{E}$ are related as follows:

$$
\sigma_{E}=\frac{V}{E} N\left(d_{1}\right) \sigma_{V} .
$$

Although this structural model approach suggests that credit spread models should include asset volatility, most empirical researchers include equity volatility in place of asset volatility (Collin-Dufresne et al. 2001, Campbell and Taksler 2003, Ericsson et al. 2009, Zhang et al. 2009). This is likely because equity volatility is directly observed, whereas asset volatility has to be inferred by making assumptions about the values of remaining variables of the model. It may also be that the model itself is a much simplified version of the capital structure of a typical firm. Thus, following an extensive literature, in our main analysis we presented our results using equity volatility as a proxy for asset volatility.

We now test the robustness of our results to using historical asset volatility in place of historical equity volatility. We estimate asset volatility $\sigma_{V}$ using an iterative procedure suggested by Bharath and Shumway (2008) to simultaneously solve Equations (10) and (11). Furthermore, some researchers have also suggested that the credit spreads are better related to implied equity volatility from equity options, which is forward looking, than to historical equity volatility, which is backward looking (Cremers et al. 2008, Cao et al. 2010). So we also report our test results using implied equity volatility as defined in Appendix C.

The first three columns of Table 8 compare the implied SOA or $\lambda$ values using historical equity volatility, historical asset volatility, and implied equity volatility. We replicate all of our GMM tests from Tables 4 and 6 and a few additional tests that are described below. We find a good deal of similarity between SOA values obtained using any of the three volatility measures. For example, for the aggregate sample from Table 4 , the SOA values equal $0.259,0.257$, and 0.255 with the three volatility measures. In the remaining tests the estimates are also quite close despite smaller sample sizes in partitions. Overall, we infer that our results related to the implied speed of adjustment from CDS spreads are robust to alternate measures of volatility.

\subsection{Using CDS Contracts of Different Maturities to Calculate Implied SOA}

Thus far we have presented implied SOA values using the combination of one-year and five-year CDS contracts. We now test combinations of other maturities to see if our results are sensitive to this choice. The last two columns of Table 8 report the SOA estimates with alternate combinations of two-year and five-year CDS contracts and one-year, two-year, and five-year CDS contracts.

Multiple panels of Table 8 show that the alternate combinations of CDS contracts give results that are reasonably similar to the original combination in all cases. For example, for the aggregate sample the implied SOA values are 0.259 with one-year and fiveyear CDS contracts, 0.224 with two-year and five-year CDS contracts, and 0.228 with one-year, two-year, and five-year CDS contracts. We thus illustrate that our estimates are robust to the choice of CDS contracts.

\subsection{Bootstrapping the $t$-Statistics of Implied SOA Values}

Tables 4 and 6 report $t$-statistics of implied SOA and other control variables that appear in the system of Equations (8), which is estimated using the GMM procedure and all available data. One may ask whether these $t$-statistics are driven by a few outlier observations. So we follow a bootstrap procedure to confirm the statistical significance of our results. We pick 5,000 observations at random from the sample of CDS contracts and estimate the implied SOA. We repeat this sampling procedure 100 times and find that the values of implied SOA lie within a small range, with a mean of 0.259 and a standard deviation of 0.012 for the aggregate sample. This upholds the statistical significance of our results. 


\begin{tabular}{|c|c|c|c|c|c|}
\hline \multirow{3}{*}{$\begin{array}{l}\text { CDS maturities included in the sample } \rightarrow \\
\text { Measure of firm volatility } \rightarrow\end{array}$} & \multicolumn{3}{|c|}{ One-year and five-year } & \multirow{2}{*}{$\begin{array}{c}\begin{array}{c}\text { Two-year and } \\
\text { five-year }\end{array} \\
\begin{array}{c}\text { Historical equity } \\
\text { volatility }\end{array}\end{array}$} & \multirow{2}{*}{$\begin{array}{c}\text { One-year, two-year, } \\
\text { and five-year } \\
\begin{array}{c}\text { Historical equity } \\
\text { volatility }\end{array}\end{array}$} \\
\hline & $\begin{array}{l}\text { Historical equity } \\
\text { volatility }\end{array}$ & $\begin{array}{l}\text { Historical asset } \\
\text { volatility }\end{array}$ & $\begin{array}{l}\text { Implied equity } \\
\text { volatility }\end{array}$ & & \\
\hline & $(8.1)$ & $(8.2)$ & (8.3) & $(8.4)$ & (8.5) \\
\hline Description $\downarrow$ & Implied $\lambda$ & Implied $\lambda$ & Implied $\lambda$ & Implied $\lambda$ & Implied $\lambda$ \\
\hline \multicolumn{6}{|c|}{ Panel A: No partitions (Table 4) } \\
\hline Aggregate sample & 0.259 & 0.257 & 0.255 & 0.224 & 0.228 \\
\hline \multicolumn{6}{|c|}{ Panel B: Partitions based on implications of pecking order and trade-off theories (Table 6, models (6.1) and (6.2)) } \\
\hline $\begin{array}{l}\text { Predicted low speed (P1, P4) } \\
\text { Predicted high speed (P2, P3) }\end{array}$ & $\begin{array}{l}0.173 \\
0.339\end{array}$ & $\begin{array}{l}0.164 \\
0.334\end{array}$ & $\begin{array}{l}0.176 \\
0.332\end{array}$ & $\begin{array}{l}0.139 \\
0.301\end{array}$ & $\begin{array}{l}0.141 \\
0.307\end{array}$ \\
\hline \multicolumn{6}{|c|}{ Panel C: Partitions based on implications of market timing and trade-off theories (Table 6, models (6.3) and (6.4)) } \\
\hline $\begin{array}{l}\text { Predicted low speed (M1, M4) } \\
\text { Predicted high speed (M2, M3) }\end{array}$ & $\begin{array}{l}0.231 \\
0.315\end{array}$ & $\begin{array}{l}0.243 \\
0.276\end{array}$ & $\begin{array}{l}0.228 \\
0.305\end{array}$ & $\begin{array}{l}0.191 \\
0.289\end{array}$ & $\begin{array}{l}0.189 \\
0.299\end{array}$ \\
\hline \multicolumn{6}{|c|}{ Panel D: Partitions based on implications of all three theories (Table 6, models (6.5), (6.6), and (6.7)) } \\
\hline $\begin{array}{l}\text { Predicted very low speed (PM1, PM8) } \\
\text { Predicted medium speed (PM3 to PM6) } \\
\text { Predicted very high speed (PM2, PM7) }\end{array}$ & $\begin{array}{l}0.127 \\
0.299 \\
0.363\end{array}$ & $\begin{array}{l}0.136 \\
0.288 \\
0.332\end{array}$ & $\begin{array}{l}0.132 \\
0.299 \\
0.360\end{array}$ & $\begin{array}{l}0.105 \\
0.265 \\
0.329\end{array}$ & $\begin{array}{l}0.101 \\
0.270 \\
0.341\end{array}$ \\
\hline \multicolumn{6}{|c|}{ Panel E: Partitions formed by firm size } \\
\hline $\begin{array}{l}\text { Small firms below median }\left(\$ 2.8 \text { billion }^{\dagger}\right) \\
\text { Large firms above median }\left(\$ 14.8 \text { billion }^{\dagger}\right)\end{array}$ & $\begin{array}{l}0.212 \\
0.291\end{array}$ & $\begin{array}{l}0.175 \\
0.268\end{array}$ & $\begin{array}{l}0.197 \\
0.263\end{array}$ & $\begin{array}{l}0.180 \\
0.281\end{array}$ & $\begin{array}{l}0.187 \\
0.278\end{array}$ \\
\hline \multicolumn{6}{|c|}{ Panel F: Partitions formed by Fama and French five-industry classification } \\
\hline $\begin{array}{l}\text { Consumer } \\
\text { Health } \\
\text { Hi-Tech } \\
\text { Manufacturing } \\
\text { Other }\end{array}$ & $\begin{array}{l}0.261 \\
0.406 \\
0.031 \\
0.245 \\
0.254\end{array}$ & $\begin{array}{l}0.385 \\
0.393 \\
0.004 \\
0.282 \\
0.388\end{array}$ & $\begin{array}{l}0.272 \\
0.418 \\
0.027 \\
0.241 \\
0.277\end{array}$ & $\begin{array}{l}0.211 \\
0.343 \\
0.014 \\
0.231 \\
0.186\end{array}$ & $\begin{array}{l}0.217 \\
0.371 \\
0.009 \\
0.220 \\
0.196\end{array}$ \\
\hline
\end{tabular}

Notes. Panels $A$ to $D$ test the robustness of implied speed of leverage adjustment $(\lambda)$ results from Tables 4 and 6 under two variations. First, we replace historical equity volatility by historical asset volatility or implied equity volatility while using a combination of one-year and five-year CDS contracts. Second, we test either a combination of two-year and five-year CDS contracts or a combination of one-year, two-year, and five-year CDS contracts while using historical equity volatility. The volatility measures are defined in Appendix C. Panels $E$ and $F$ test the speed of leverage adjustment across partitions formed by firm size and by Fama and French (1997) five-industry classification.

${ }^{\dagger}$ Median market value of equity for firms included in the subsample.

\subsection{Patterns in Implied SOA Across Partitions Formed by Firm Size}

Firm size is a key variable, and it is important to know how it relates to SOA. This relation is also important in comparing our results to the results in previous literature because our firms with traded CDS contracts tend to be bigger than all Compustat firms examined in many studies. Large firms face lower transaction costs, which may increase their SOA. However, Alti (2006) and Flannery and Rangan (2006) argue that some small firms grow quickly, which may reduce their costs of adjusting leverage and increase their SOA. Empirically, Flannery and Rangan (2006) divide their sample into four subsets based on firm size. They report SOA values of 0.273 for subset 1 (largest firms belonging to New York Stock Exchange deciles 1 and 2), 0.426 for subset 2 (deciles 3 and 4), 0.514 for subset 3 (deciles 5, 6, and 7), and 0.392 for
Subset 4 (deciles 8, 9, and 10). One concern with their results may be that smaller firms have shorter time series, which may increase their look-ahead bias as shown in our Table 7.

Our sample does not include the smallest firms included in the Flannery and Rangan (2006) sample, so we form two subsets based on whether the firm size (market value of equity) is above or below the median firm size. Panel $\mathrm{E}$ of Table 8 shows that the two subsets have firms with median market values of equity equal to $\$ 2.8$ billion and $\$ 14.8$ billion. The SOA values equal 0.212 and 0.291 for these subsets of small firms and large firms using our base model and methodology. The difference of 0.079 is statistically significant at the $1 \%$ level. We infer that SOA increases with firm size, consistent with lower transaction costs of making leverage adjustments facing large firms. 


\subsection{Patterns in Implied SOA Across Industries}

It is well known that different industries have different leverage norms (MacKay and Phillips 2005). So we examine whether different industries also have different SOA toward predicted leverage. We divide our sample into five Fama and French (1997) industries: consumer, health, hi-tech, manufacturing, and other. Within each industry we calculate implied SOA using different combinations of CDS contracts. The results are shown in the panel $\mathrm{F}$ of Table 8.

Averaged across models (8.1), (8.4), and (8.5), the implied SOA equals $0.230,0.373,0.018,0.232$, and 0.212 for the five industries listed above. Three of these estimates are close to the SOA estimate for the aggregate sample-those for consumer, manufacturing, and other industries. But the remaining two are quite different. The health industry has the highest SOA of 0.373 , and the hi-tech industry has the lowest SOA of 0.018 . These deviations make sense for the following reason. Health stocks have a low beta and low volatility (besides high leverage), whereas the opposite is true of hi-tech stocks. ${ }^{8}$ Higher volatility is associated with more frequent undervaluation or overvaluation of equity and increases the role of market timing relative to other theories. These results increase our understanding of how leverage rebalancing considerations vary from industry to industry.

\section{Conclusion}

Few issues have attracted as much attention in the finance literature as capital structure. Three major theories dominate this literature-pecking order, market timing, and trade-off. A large part of this literature has been devoted to understanding whether firms have a target leverage predicted by trade-off theory and, if so, at what speed firms adjust their leverage toward their target leverage in the presence of transaction costs and the other two theories. More recent literature argues that the target leverage thus estimated should be thought of as the simpler predicted leverage, given that some elements that are used in deriving the target are also consistent with the alternate theories. Empirically, researchers have relied uniquely on the time series of leverage changes to measure the SOA. Several features of this approach have been the subject of much criticism. In this paper, we propose and test a new technique of measuring SOA that surveys investors' expectations of future leverage values built into the prices of credit instruments and is not subject to such criticism.

\footnotetext{
${ }^{8}$ Over the period February 2004 to December 2010, Vanguard Health Care ETF (ticker VHT) had a beta of 0.66 and an annualized volatility of $14 \%$. In comparison, Vanguard Information Technology ETF (ticker VGT) had a beta of 1.13 and an annualized volatility of $21 \%$.
}

Using a GMM approach we show that in the aggregate sample of all firms with traded CDS contracts during 2000 to 2007 , the SOA equals $26 \%$. This estimate is robust to alternate specifications of the sample and of certain variables such as firm volatility. More importantly, we find that the SOA varies considerably across several partitions formed by the intersection of the three capital structure theories as expected. We therefore conclude that investors' expectations embedded in the prices of credit instruments are formed in accordance with the implications of all three theories of capital structure.

Our methodology also sheds new light on a few controversial issues in the previous literature. First, we show that the inclusion of firm fixed effects in the predicted leverage model leads to noisier estimates of investors' expectations concerning the future evolution of firm leverage. Apparently, the look-ahead bias introduced by firm fixed effects dominates the benefits of capturing any unspecified and residual firm-specific heterogeneity. As a result, SOA falls to $17 \%$ with the inclusion of firm fixed effects in the predicted leverage model. Similar to the findings of Chang and Dasgupta (2009) and Lemmon et al. (2008), we find that industry-specific information plays an important role in forming investor expectations about the evolution of firm leverage. Thus, we recommend the inclusion of industry fixed effects in the predicted leverage model. Second, we find that initial leverage at the time when a firm is first added to the Compustat database is a poor proxy for its predicted leverage in later years. This evidence is consistent with the results of DeAngelo and Roll (2011), who show that leverage for individual firms varies considerably over time. Above all, we contribute to a mature but growing literature on capital structure by illustrating that one can extract valuable information from investors' expectations of future leverage changes embedded in the prices of credit instruments.

\section{Supplemental Material}

Supplemental material to this paper is available at http://dx .doi.org/10.1287/mnsc.2013.1871.

\section{Acknowledgments}

The authors are very obliged to department editor Jerome Detemple and an anonymous referee of Management Science for several suggestions that improved this paper in many ways. They have also benefited from the comments of seminar participants at the Hong Kong University of Science and Technology, University of Iowa, Korea Advanced Institute of Science and Technology, University of Massachusetts at Amherst, Nanyang Technological University of Singapore, National University of Singapore, Singapore Management University, and Sungkyunkwan University of Korea. 


\section{Appendix A. Comparison of Speed of Leverage Adjustment Estimates}

Panel A: Speed of leverage adjustment estimates based on the time series of realized leverage changes

Fama and French (2002)

Flannery and Rangan (2006)

Frank and Goyal (2007)

Kayhan and Titman (2007)

Lemmon et al. (2008)

Huang and Ritter (2009)

Lockhart (2014)

Hovakimian and Li (2011)
$7 \%-18 \%$ Lower (upper) estimates for dividend payers (nonpayers)

$34 \%-38 \%$ Include firm fixed effects

$55 \% \quad$ Include CEO fixed effects

$10 \% \quad$ Based on how much leverage deviation persists after five years

$25 \%-39 \%$ Lower number based on GMM and no firm fixed effects; higher number based on OLS and firm fixed effects

$17 \% \quad$ Use a differencing length of eight years

$24 \%-31 \%$ Lower (upper) estimates for firms without (with) access to credit line, with firm fixed effects

$17 \%-36 \%$ Lower (upper) estimates for firm fixed effects using historical (full sample) panel

Panel B: Implied speed of leverage adjustment estimates based on expected leverage changes priced into CDS spreads

This study

$13 \%-36 \%$ Implied by CDS contracts of different maturities

$-25.9 \%$ in the aggregate sample with industry and year fixed effects included in the predicted leverage model

$-19.6 \%$ in the aggregate sample with the removal of industry fixed effects, which further reduces to $17.0 \%$ with the addition of firm fixed effects (in contrast with previous literature)

- Varies between $13 \%$ and $36 \%$ across subsamples formed by whether the three theories (trade-off, pecking order, and market timing) predict leverage adjustment in the same or opposite directions, with industry and year fixed effects

\section{Appendix B. Control Variables in the Credit Spread Models and Their Predicted Coefficients}

Our complete model of corporate bond spreads is specified as follows:

$$
\begin{aligned}
& \text { Bond spread } \\
& \begin{aligned}
= & b_{0}+b_{1} \text { Leverage }+b_{2} \text { Predicted leverage } \\
& +b_{3} \text { Historical volatility of firm }+b_{4} \text { Log total assets } \\
& +b_{5} \text { Coupon }+b_{6} \text { Years to maturity }+b_{7} \text { Bond age } \\
& +b_{8} \text { 10-year Treasury bond yield }+b_{9} \text { Term spread } \\
& +b_{10} \text { Default spread }+b_{11} \text { Market volatility }(\text { VIX) } \\
& +b_{12} \text { Market return }+ \text { Error term } .
\end{aligned}
\end{aligned}
$$

Leverage and predicted leverage are the two focus variables, and the remaining variables are control variables. Below we explain the reasons for including these control variables and their predicted coefficients from prior literature.

Historical volatility of equity (or assets). In the Merton (1974) model, asset volatility determines the probability of exercise of the put option the bondholders sell to the equityholders. Equity volatility is directly observed, and Campbell and Taksler (2003) argue that it can serve as a proxy for asset volatility. We present equity volatility in the main analysis, but we also show that our results are similar with asset volatility. The coefficient of either variable is predicted to be positive.

Log total assets. Larger firms have higher name recognition, less information asymmetry, and hence greater access to capital markets. This makes the credit risk premium smaller by reducing investors' uncertainty. Larger firms also have more actively traded bonds, and liquidity increases bond prices.

Coupon. Elton et al. (2001) argue that higher coupon bonds are less desirable than lower coupon bonds because they incur higher taxes throughout their life. The coefficient of Coupon is predicted to be positive. To balance the picture, Campbell and Taksler (2003) argue that higher coupons shorten the bond duration, which could reduce the default risk and hence the bond spread.

Years to maturity. The higher the bond life, the greater the default risk, so the coefficient of Years to maturity is predicted to be positive.

Bond age. Recently issued corporate bonds are more liquid than older bonds. For Treasury bonds this is known as onthe-run versus off-the-run phenomenon. The coefficient of Bond age is predicted to be positive.

10-year Treasury bond yield. In structural models, the riskfree interest rate increases the drift term of the stochastic process for asset value and reduces the probability of default. Duffee (1998) empirically shows that the 10-year Treasury bond yield acts as a proxy for the risk-free interest rate. Its coefficient is predicted to be negative.

Term spread: Collin-Dufresne et al. (2001) argue that a higher term spread is an indicator of improving economy as well as increasing future risk-free rates. On both counts the default risk decreases, so its coefficient is expected to be negative.

Default spread. This is a measure of the default risk as well as default risk premium in the bond market, and its coefficient is predicted to be positive.

Market volatility. We measure market volatility by the VIX index. This is intended to capture the default risk in the economy, which summarizes the default risk of individual firms. It is forward looking, as it is inferred from option prices on the S\&P 500 index. Its coefficient is predicted to be positive.

Market return. The 180-day market return captures the effect of an improving economy that lowers default risk, so its coefficient is predicted to be negative. However, 
Campbell and Taksler (2003) motivate their paper by documenting that over the 1990s there was an increase in both the market level and idiosyncratic volatility. Thus, a higher market return may also capture increasing asset volatility, which would predict a positive coefficient.

Finally, when analyzing CDS spreads, we include all control variables used for bond spreads and listed in model (B1) except the bond-specific parameters. The revised model is specified as follows:

$$
\begin{aligned}
\text { CDS } & \text { spread } \\
= & c_{0}+c_{1} \text { Leverage }+c_{2} \text { Predicted leverage } \\
& +c_{3} \text { Historical volatility of firm }+c_{4} \text { Log total assets } \\
& +c_{5} \text { 10-year Treasury bond yield }+c_{6} \text { Term spread } \\
& +c_{7} \text { Default spread }+c_{8} \text { Market volatility }(\text { VIX) } \\
& +c_{9} \text { Market return }+ \text { Error term } .
\end{aligned}
$$

\begin{tabular}{|c|c|}
\hline Asset volatility & Calculated using the Merton (1974) model following Bharath and Shumway (2008) \\
\hline Bond spread & Corporate bond yield minus corresponding maturity interpolated constant maturity treasury yield \\
\hline Coupon & Annual coupon expressed as a percentage of par value \\
\hline Credit rating & $\begin{array}{l}\text { The most recent S\&P credit rating prior to the earnings announcement date; lower numbers represent } \\
\text { lower default risk }(\mathrm{AA}+=4, \mathrm{AA}=5, \ldots, \mathrm{B}-=18, \mathrm{CCC}+=19 \text {, etc.) }\end{array}$ \\
\hline Default spread & $\begin{array}{l}\text { Difference between yield of BAA rated corporate bonds and AAA rated corporate bonds as of the } \\
\text { earnings announcement date }\end{array}$ \\
\hline $\begin{array}{l}\text { Depreciation/ } \\
\text { total assets }\end{array}$ & Depreciation and amortization/total assets (DP/AT) \\
\hline Distance to default & Distance to default is computed using the Merton (1974) model following Bharath and Shumway (2008) \\
\hline EBIT/total assets & $\begin{array}{l}\text { (Interest expense }+ \text { income taxes }+ \text { income before extraordinary items }) / \text { total assets } \\
(\text { XINT }+ \text { TXT }+ \text { IB }) / \text { AT }\end{array}$ \\
\hline Equity volatility & $\begin{array}{l}\text { Volatility of daily returns is computed using 254-day period ending one day before the earnings } \\
\text { announcement date, expressed in percent, and annualized }\end{array}$ \\
\hline Financing deficit & $\begin{array}{l}\text { Quarterly financing deficit is computed following Frank and Goyal (2003); it equals dividend plus } \\
\text { investments plus change in working capital minus cash flow }\end{array}$ \\
\hline $\begin{array}{l}\text { Fixed assets/ } \\
\text { total assets }\end{array}$ & Total property, plant, and equipment/total assets (PPENT/AT) \\
\hline $\begin{array}{l}\text { Implied equity } \\
\text { volatility }\end{array}$ & Estimated from at-the-money equity put options on the underlying firm closest to 60 days to maturity \\
\hline Initial leverage & $\begin{array}{l}\text { Initial leverage is the first nonzero value of leverage for the firm in Compustat, following } \\
\text { Lemmon et al. (2008) }\end{array}$ \\
\hline Leverage & (Total long-term debt + total debt in current liabilities)/total assets (DLTT + DLC)/AT \\
\hline Market return & $\begin{array}{l}\text { One-year value-weighted market return (CRSP VWRETD) computed until one day before the } \\
\text { earnings announcement date }\end{array}$ \\
\hline Market-to-book & $\begin{array}{l}\text { (Total long-term debt }+ \text { total debt in current liabilities }+ \text { preferred stock + market value of equity) } / \\
\text { total assets (DLTT + DLC + PSTKL + PRCC_F } * \text { CSHO) } / \text { AT }\end{array}$ \\
\hline Market volatility & Chicago Board Options Exchange Volatility Index (VIX) level as of the earnings announcement date \\
\hline $\begin{array}{l}\text { Prior year excess } \\
\quad \text { return }\end{array}$ & $\begin{array}{l}\text { Cumulative stock return over a 252-day period ending one day prior to the earnings announcement } \\
\text { date minus the cumulative market return, expressed in percent }\end{array}$ \\
\hline Rated dummy & Equals 1 if firm is rated by $\mathrm{S} \& \mathrm{P}$ and 0 otherwise \\
\hline RED dummy & Equals 1 if $R \& D$ expense is missing and 0 otherwise \\
\hline $\begin{array}{l}\text { RED expense/ } \\
\text { total assets }\end{array}$ & Research and development expense/total assets (XRD/AT) \\
\hline $\begin{array}{l}\text { Selling expense/ } \\
\text { sales }\end{array}$ & Selling, general, and administrative expense/total sales (XSGA/SALE) \\
\hline Predicted leverage & The leverage toward which firm leverage moves over time \\
\hline Term spread & $\begin{array}{l}\text { Slope of the yield curve as of the earnings announcement date; 10-year-2-year constant maturity } \\
\text { Treasury yield }\end{array}$ \\
\hline $\begin{array}{c}\text { Undervaluation/ } \\
\text { overvaluation }\end{array}$ & $\begin{array}{l}\text { Measured by prior-year excess return, the difference between stock return and market return over a } \\
\text { 250-day period ending before the earnings announcement date }\end{array}$ \\
\hline
\end{tabular}

\section{Appendix C. Variable Definitions}

Variable Definition (including Compustat variable names in parentheses where applicable) 


\section{Appendix D. Estimating Predicted Leverage}

Panel A: Summary statistics of variables analyzed in this table

\begin{tabular}{|c|c|c|c|c|}
\hline Variable & Mean & Q1 & Median & Q3 \\
\hline Leverage $(\%)$ & 23.8 & 8.4 & 22.0 & 35.2 \\
\hline Total assets (TA) (\$ millions) & 1,157 & 30 & 101 & 418 \\
\hline EBIT/TA & 0.083 & 0.044 & 0.100 & 0.155 \\
\hline Market to book & 1.479 & 0.737 & 1.051 & 1.679 \\
\hline Depreciation/TA & 0.044 & 0.025 & 0.038 & 0.055 \\
\hline Fixed assets/TA & 0.305 & 0.148 & 0.264 & 0.418 \\
\hline$R \mathcal{E} D$ dummy & 0.432 & 0.000 & 0.000 & 1.000 \\
\hline RED expense/TA & 0.028 & 0.000 & 0.000 & 0.032 \\
\hline Selling expense/sales & 0.261 & 0.125 & 0.207 & 0.318 \\
\hline
\end{tabular}

Panel B: Estimation of predicted leverage

\begin{tabular}{|c|c|c|c|}
\hline \multirow[b]{2}{*}{ Independent variables $X_{i, t}$} & \multicolumn{3}{|c|}{ Dependent variable is $L e v_{i, t+1}$} \\
\hline & (D.1) & (D.2) & (D.3) \\
\hline Log total assets & $\begin{array}{r}0.002 \\
(5.40)\end{array}$ & $\begin{array}{r}0.011 \\
(29.38)\end{array}$ & $\begin{array}{r}0.019 \\
(20.18)\end{array}$ \\
\hline EBIT/TA & $\begin{array}{r}-0.304 \\
(-57.44)\end{array}$ & $\begin{array}{r}-0.281 \\
(-52.92)\end{array}$ & $\begin{array}{r}-0.185 \\
(-35.32)\end{array}$ \\
\hline Market to book & $\begin{array}{r}-0.010 \\
(-18.51)\end{array}$ & $\begin{array}{r}-0.007 \\
(-12.56)\end{array}$ & $\begin{array}{l}-0.004 \\
(-6.50)\end{array}$ \\
\hline Depreciation/TA & $\begin{array}{r}-0.446 \\
(-16.45)\end{array}$ & $\begin{array}{l}-0.231 \\
(-8.71)\end{array}$ & $\begin{array}{r}-0.345 \\
(-10.78)\end{array}$ \\
\hline Fixed assets/TA & $\begin{array}{r}0.214 \\
(48.39)\end{array}$ & $\begin{array}{r}0.186 \\
(48.41)\end{array}$ & $\begin{array}{r}0.157 \\
(24.82)\end{array}$ \\
\hline RED dummy & $\begin{array}{c}0.012 \\
(7.77)\end{array}$ & $\begin{array}{r}0.028 \\
(19.94)\end{array}$ & $\begin{array}{l}-0.004 \\
(-2.12)\end{array}$ \\
\hline RED expense/TA & $\begin{array}{r}-0.445 \\
(-25.88)\end{array}$ & $\begin{array}{r}-0.469 \\
(-29.07)\end{array}$ & $\begin{array}{l}-0.204 \\
(-9.16)\end{array}$ \\
\hline Selling expenses/sales & $\begin{array}{r}-0.066 \\
(-16.78)\end{array}$ & $\begin{array}{l}-0.013 \\
(-3.47)\end{array}$ & $\begin{array}{l}-0.011 \\
(-2.07)\end{array}$ \\
\hline Rated dummy & $\begin{array}{r}0.106 \\
(49.95)\end{array}$ & $\begin{array}{r}0.097 \\
(45.12)\end{array}$ & $\begin{array}{r}0.053 \\
(24.66)\end{array}$ \\
\hline Year fixed effects & Yes & Yes & Yes \\
\hline Fama and French (1997) 48-industry fixed effects & Yes & No & No \\
\hline Firm fixed effects & No & No & Yes \\
\hline$N$ & 100,945 & 100,945 & 100,945 \\
\hline
\end{tabular}

Notes. We estimate the following model of predicted leverage: $L e v_{i, t+1}=X_{i, t} \beta+\epsilon_{i, t}$, where $L e v_{i, t+1}$ denotes the leverage of firm $i$ during period $t+1$ (next year), $X_{i, t}$ is a vector of firm characteristics during period $t$ (current year), $\beta$ is the vector of coefficients, and $\epsilon_{i, t}$ is the error term. In panel A we report the firm characteristics, which are defined in Appendix C. Models (D.1) and (D.2) in panel B are estimated using a pooled Tobit regression model that constrains the dependent variable to lie between 0 and 100 following Kayhan and Titman (2007). Model (D.3) is estimated using a panel regression technique following Flannery and Rangan (2006). All three models include year fixed effects, only (D.1) includes industry fixed effects, and only (D.3) includes firm fixed effects. There is no constant term as a result of fixed effects. The sample includes 100,945 firm-years during 1967 to 2007 with available data on CRSP and Compustat. All models include the full panel of data. We report $t$-statistics based on maximum likelihood estimates of the coefficient standard errors in parentheses. The $t$-statistics greater than $2.58,1.96$, and 1.64 are statistically significant at the $1 \%, 5 \%$, and $10 \%$ levels, respectively.

\section{References}

Almeida H, Philippon T (2007) The risk-adjusted cost of financial distress J. Finance 62:2557-2586.

Alti A (2006) How persistent is the impact of market timing on capital structure? J. Finance 61:1681-1710.

Baker M, Wurgler J (2002) Market timing and capital structure. J. Finance 57:1-32.
Bessembinder H, Kahle K, Maxwell W, Xu D (2009) Measuring abnormal bond performance. Rev. Financial Stud. 22: $4219-4258$.

Bharath S, Shumway T (2008) Forecasting default with the Merton distance to default model. Rev. Financial Stud. 21:1339-1369.

Bond S (2002) Dynamic panel data models: A guide to micro data methods and practice. Portuguese Econom. J. 1:141-162. 
Byoun S (2008) How and when do firms adjust their capital structures toward targets. J. Finance 63:3069-3096.

Campbell J, Taksler G (2003) Equity volatility and corporate bond yields. J. Finance 58:2321-2349.

Cao C, Yu F, Zhong Z (2010) The information content of optionimplied volatility for credit default valuation. J. Financial Markets 13:321-343.

Chang X, Dasgupta S (2006) Target behavior and financing: How conclusive is the evidence? Working paper, Hong Kong University of Science and Technology, Clear Water Bay.

Chang X, Dasgupta S (2009) Target behavior and financing: How conclusive is the evidence? J. Finance 64:1767-1796.

Collin-Dufresne P, Goldstein R (2001) Do credit spreads reflect stationary leverage ratios? J. Finance 56:1929-1957.

Collin-Dufresne P, Goldstein R, Martin JS (2001) The determinants of corporate credit spreads. J. Finance 56:2177-2207.

Cremers M, Driessen J, Maenhout P, Weinbaum D (2008) Individual stock-option prices and credit spreads. J. Banking Finance 32:2706-2715.

DeAngelo H, Roll R (2011) How stable are corporate capital structures? Working paper, University of Southern California, Los Angeles.

Dick-Nielsen J (2009) Liquidity biases in TRACE. J. Fixed Income 19:43-55.

Donaldson G (1961) Corporate debt capacity: A study of corporate debt policy and the determination of corporate debt capacity. Working paper, Harvard Business School, Boston.

Duarte J, Young L, Yu F (2007) Why does corporate governance explain credit spreads? Working paper, Rice University, Houston.

Duffee G (1998) The relation between Treasury yields and corporate bond yield spreads. J. Finance 53:2225-2241.

Elton EJ, Gruber MJ, Agrawal D, Mann C (2001) Explaining the rate spread on corporate bonds. J. Finance 56:247-277.

Ericsson J, Jacobs K, Oviedo R (2009) The determinants of credit default swap premia. J. Financial Quant. Anal. 44:109-132.

Ericsson J, Reneby J, Wang H (2005) Can structural models price default risk? Evidence from bond and credit derivative markets. Working paper, McGill University, Montreal.

Fama E, French K (1997) Industry cost of equity. J. Financial Econom. 43:153-193.

Fama E, French K (2002) Testing trade-off and pecking order predictions about dividends and debt. Rev. Financial Stud. 15:1-33.

Fama E, French K (2005) Financing decisions: Who issues stock. J. Financial Econom. 76:549-582.

Faulkender M, Flannery M, Hankins K, Smith J (2012) Cash flows and leverage adjustments. J. Financial Econom. 103:632-646.

Fischer E, Heinkel R, Zechner J (1989) Dynamic capital structure choice: Theory and tests. J. Finance 45:19-40.

Flannery M, Hankins K (2012) Estimating dynamic panel models in corporate finance. J. Corporate Finance 19:1-19.

Flannery M, Rangan K (2006) Partial adjustment toward target capital structures. J. Financial Econom. 79:469-506.

Flannery M, Nikolova S, Öztekin Ö (2012) Leverage expectations and bond credit spreads. J. Financial Quant. Anal. 47:689-714.
Frank M, Goyal V (2003) Testing the pecking order theory of capital structure. J. Financial Econom. 67:217-248.

Frank M, Goyal V (2007) Corporate leverage: How much do managers really matter? Working paper, University of Minnesota, Minneapolis.

Goldstein R, Ju N, Leland H (2001) An EBIT-based model of dynamic capital structure. J. Bus. 74:483-512.

Graham J, Harvey C (2001) The theory and practice of corporate finance: Evidence from the field. J. Financial Econom. 60: 187-243.

Harford J, Klasa S, Walcott N (2009) Do firms have leverage targets? Evidence from acquisitions. J. Financial Econom. 93:1-14.

Hovakimian A, Li G (2011) In search of conclusive evidence: How to test for adjustment to target capital structure. J. Corporate Finance 17:33-44.

Huang R, Ritter J (2009) Testing theories of capital structure and estimating the speed of adjustment. J. Financial Quant. Anal. 44:237-271.

Kayhan A, Titman S (2007) Firms' histories and their capital structures. J. Financial Econom. 83:1-32.

Lemmon M, Roberts M, Zender J (2008) Back to the beginning: Persistence and cross-section of corporate capital structure. J. Finance 63:1575-1608.

Lockhart B (2014) Credit lines and leverage adjustments. J. Corporate Finace 25:274-288.

Longstaff F, Mittal S, Neis E (2005) Corporate yield spreads: Default risk or liquidity? New evidence from the credit default swap market. J. Finance 60:2213-2253.

Loughran T, Ritter J (1995) The new issues puzzle. J. Finance 50: 23-51.

MacKay P, Phillips G (2005) How does industry affect firm financial structure? Rev. Financial Stud. 18:1433-1466.

Merton R (1974) On the pricing of corporate debt: The risk structure of interest rates. J. Finance 29:449-470.

Myers S (1984) The capital structure puzzle. J. Finance 39: 575-592.

Pan J, Singleton K (2008) Default and recovery implicit in the term structure of sovereign CDS spreads. J. Finance 63: 2345-2384.

Parsons C, Titman S (2009) Empirical capital structure: A review. Foundations and Trends in Finance 3:1-93.

Rajan R, Zingales L (1995) What do we know about capital structure? Some evidence from international data. J. Finance 50:1421-1460.

Rubinstein M (1994) Implied binomial trees. J. Finance 49:771-818.

Shyam-Sunder L, Myers S (1999) Testing static tradeoff against pecking order models of capital structure. J. Financial Econom. 51:219-244

Titman S, Wessels R (1988) The determinants of capital structure choice. J. Finance 43:1-19.

Woolridge J (2002) Econometric Analysis of Cross Section and Panel Data (MIT Press, Cambridge, MA).

Yu F (2005) Accounting transparency and the term structure of credit spreads. J. Financial Econom. 75:53-84.

Zhang B, Zhou H, Zhu H (2009) Explaining credit default swap spreads with the equity volatility and jump risks of individual firms. Rev. Financial Stud. 22:5099-5131. 